\title{
الاستصلاح وأثره في فقه المعاملات
}

*

د. عبد المحمود بلال منير

مقدمة:

إن الفقه الإسلامي في جملته قائم على أساس اعتبار مصالح الناس، فكل ما هو

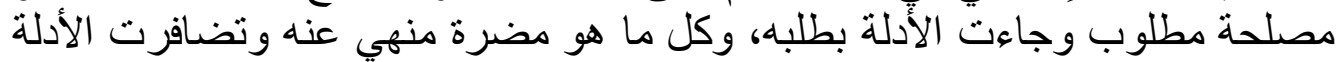

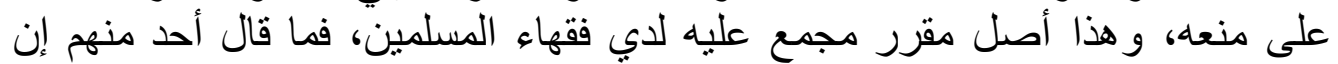
الثريعة الإسلامية جاءت بأمر ليس فيه مصلُحة العباد، وما فال فال أحد منهم أنه يجوز

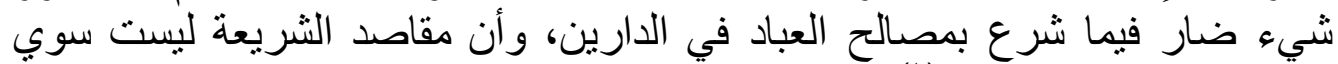

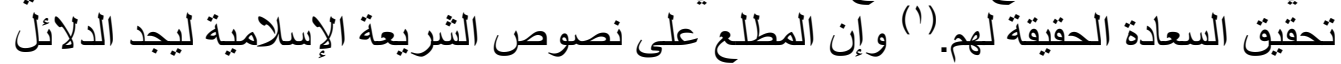

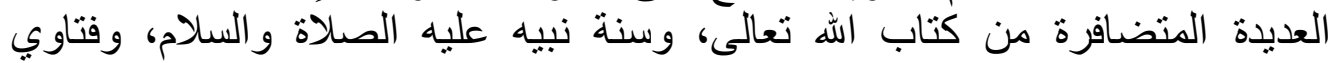

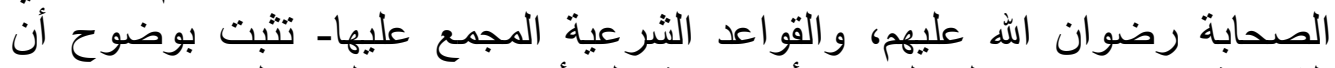

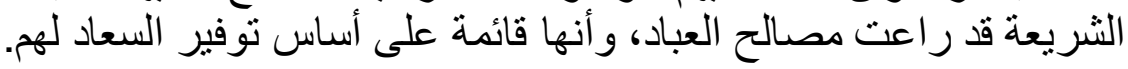

\section{تعريف المصلحة}

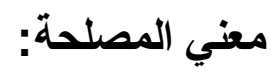

المصلحة لغة كالمنفعة وزنأ ومعني، فهي مصدر الصلاح، كالمنفعة بمعني النفع. أو هي للواحدة من المصالح، وقد صرح صاحب لسان العرب بالوجهين فقال:

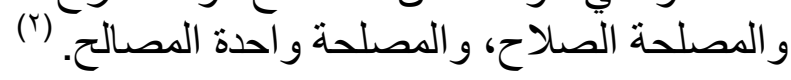

فكل ما كان فيه سو اء كان الجلب و التحصيل: كاستحصال الفوائد، واللذات، أو بالدفع و الإتقاء: كاستبعاد المضار والهو آلآم- فهو جدير بأن يسمي مصلحة. وأما في اصطلاح علماء الشريعة الإسلامية فهي: المنفعة التي قصدها الشارع الحكيم لعباده. من حفظ دينهم، ونفوسهم وعقولهم * أستاذ مشارك في كلية الثريعة والقانون ورئيس قسم السياسة الثرعية بجامعة أم درمان الإسلامية 
و نسلهم، و أمو الهم، طبق ترتيب معين فيما بينها.

و المنفعة هي اللذة، أو ما كان وسيلة إليها، ودفع الألم، أو ما كان وسيلة إليه،

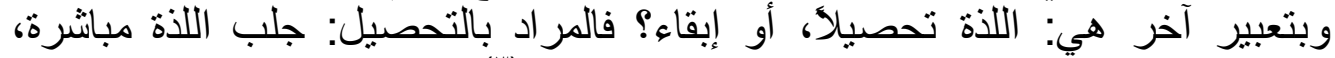

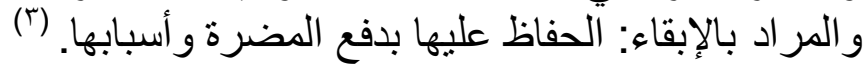

\section{المصالح المرسلة:}

و هي المصالح التي لم يقم دليل من الثارع على اعتبار ها ولا على إلغائها، فإذإ إنا

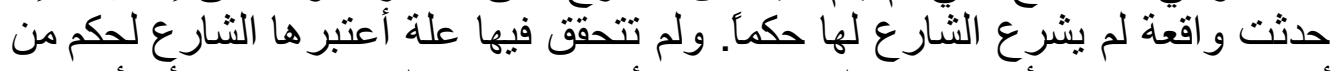

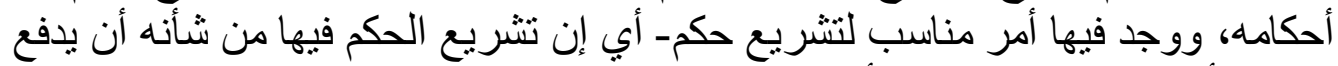

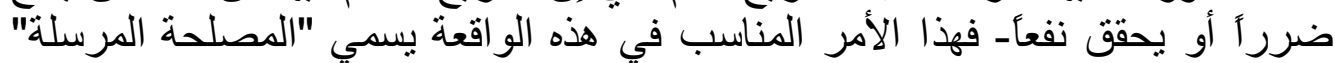

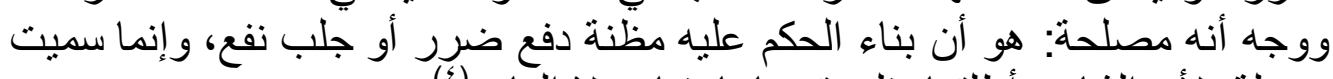

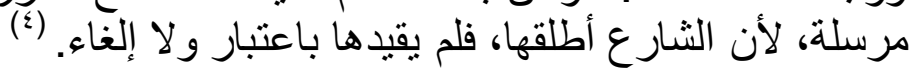

\section{مجال النظر إلى المصالح في الأحكام والعمل بالمصلحة المرسلة}

يقرر فقهاء المسلمين: أن الأعمال التي يكلف بها المسلم، وتأخذ أحكاما شرعية،

قسمان: قسم يتصل بالعبادات، وقسم العبادات.

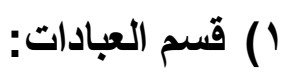

و هي كل من شأنه تنظيم العلاقة بين الإنسان وربه، وفلما تكون له علاقة ببنى

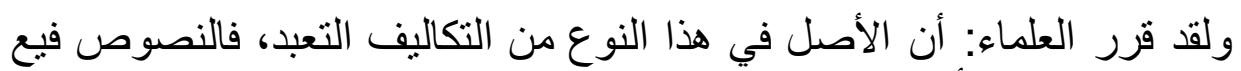

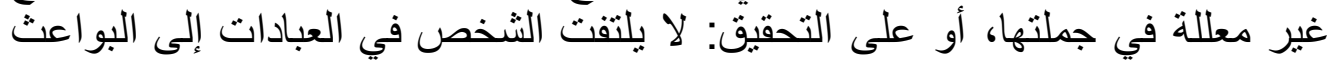

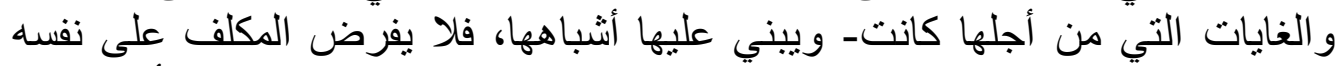

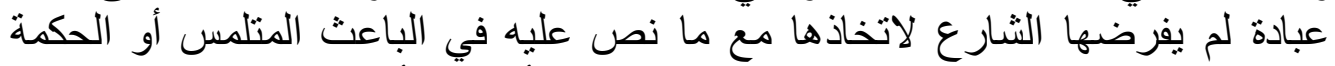
المناسبة، ويستدل الثناطبي في المو افقات على هذه الأصول بأل بأدلة ثناثنة:

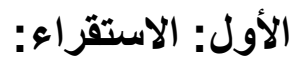

فإنا وجدنا الطهارة تتعدي محل موجبها وكذلك الصلوات خصت بأفعال

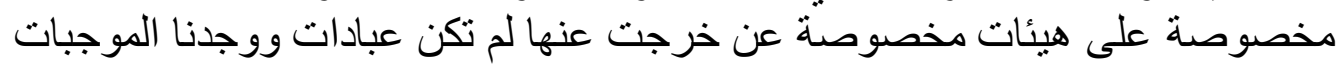
فيها تتحد مع اختلاف الموجبات، وأن الذكر المخصوص في هينة هئة ما مطلوب، وفي هيئة 
أخري غير مطلوب، و أن طهارة الحدث مخصوصة بالماء الطهور ، و إن أمكنت النظافة

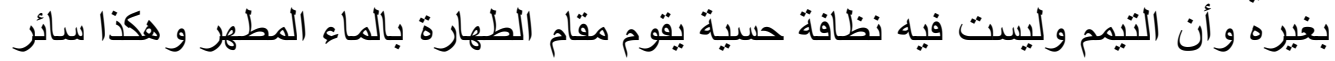
العبادات.

الثاني: أنه لو كان المقصود التوسعة في وجوه التعبد بما حد وما لم يحد لنصب الثاد التارع

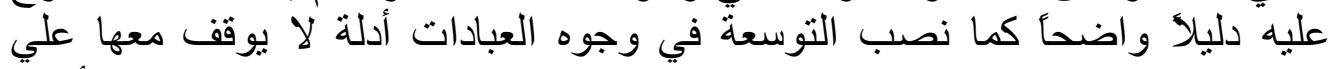

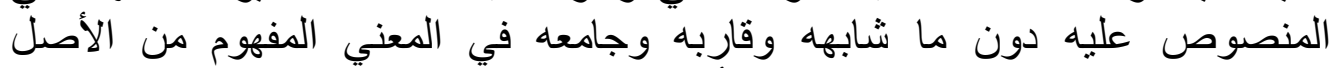

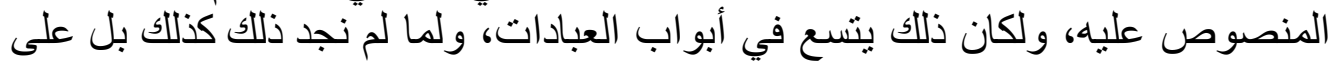

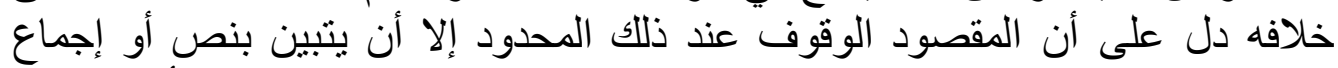

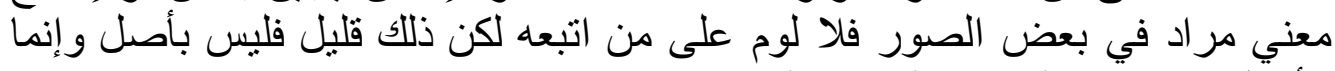
الأصل ما عم في الباب و فلب في في الموضع. فل فوم على

الثالث: أن وجوه التعبدات في أزمنة الفترات لم يهتد إليها العقلاء اهتداءهم لوجوه معاني

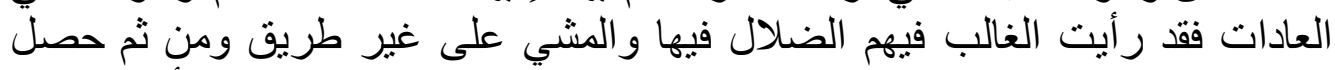

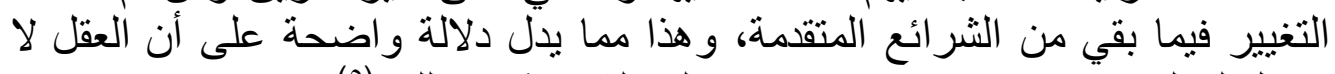

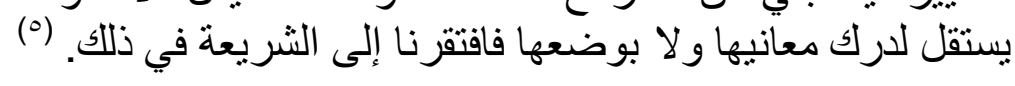

هذا على أنه من الواجب على المسلمين بأن هذه التكلفة المتصلة بالعبادات في

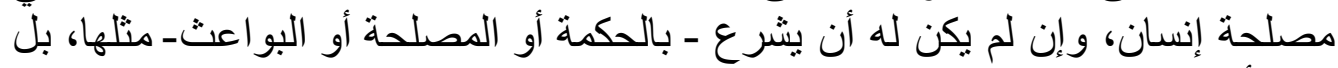

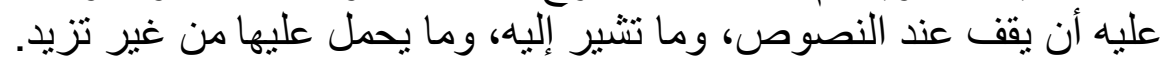

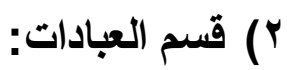

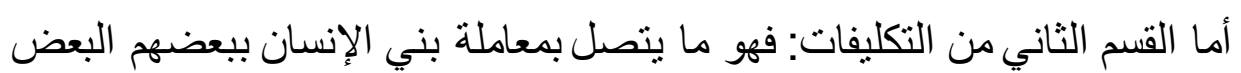
و هو ما يسمي في اصطلاح الفقهاء بالعبادات. لمات.

و الأصل في هذا القسم الالتفات إلى المعاني و البواعث التي شرعت من أجلها

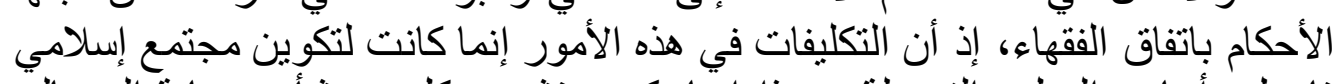

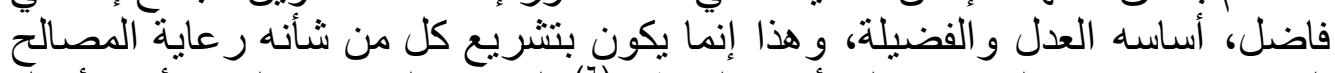

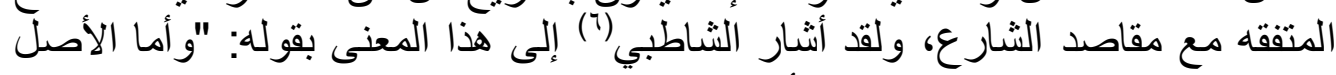
في العادات الالتفات إلى الإمعان فالأمور.

أولها: الاستقراء: فإنا وجدانا الثارع قاصداَ لمصالح العباد، والأحكام العادية

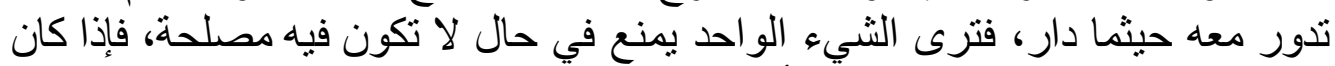

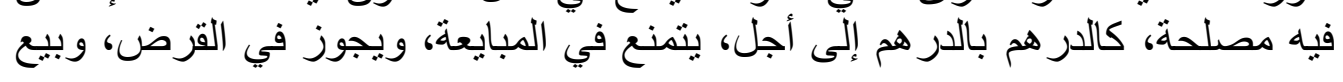


الرطب باليابس، بمتنع حيث يكون مجرد غرر وربا من غير مصلحة، ويجوز إذا كان

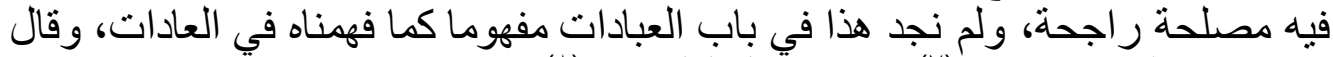

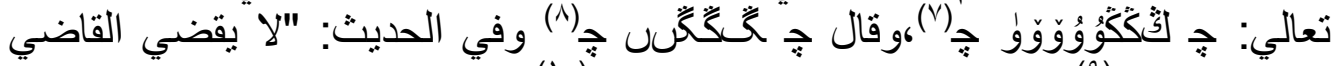

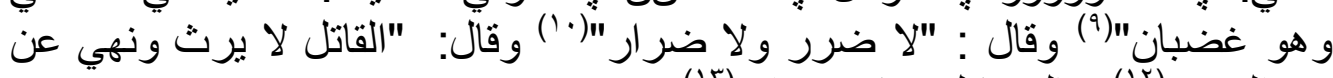

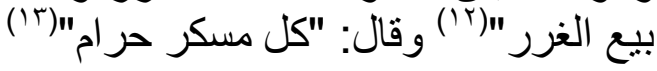

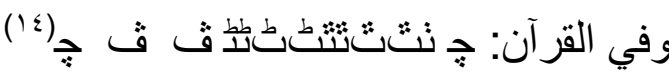

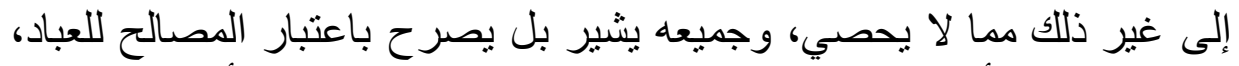

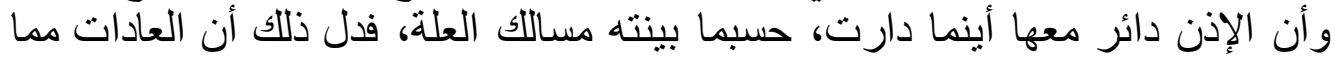
اعتمد الثار ع فيها الالتفات دائر إلى المعاني.

و الثاني: أن الثارع توسع في بيان العلل و الحكم في تشريع باب العادات كما تقدم

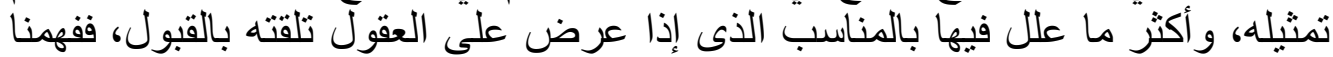

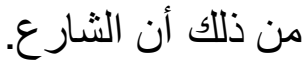
قصد فيها إتباع المعاني، لا الوقوف مع النصوص، بخلاف باب العبادات، فإن المعلوم فيهع خلاف ذلك.

و الثالث: إن الالتفات إلى المعاني قد كان معلوما في الفترات، واعتمد عليه

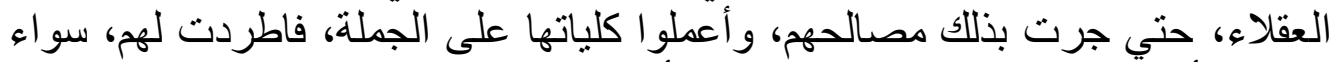

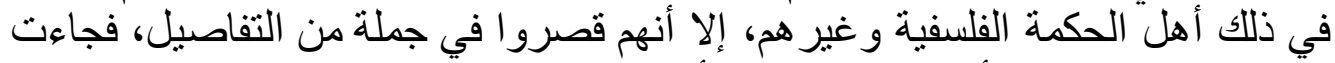

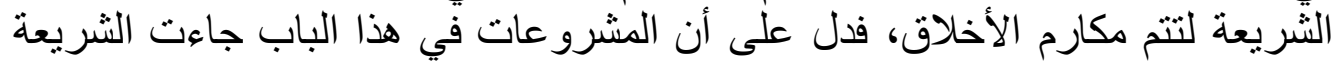

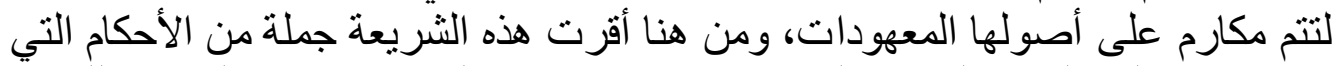

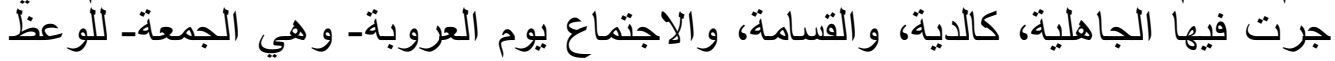

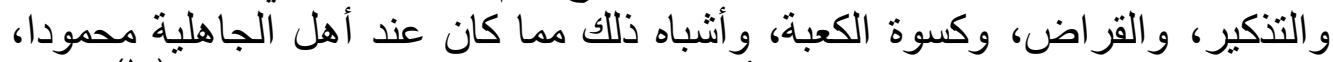
وما كان من محاسن العو ائد ومكارم الأخلاق التي تقبلها العقول، وهي ذهي كثيرة. (10)

\section{مجال العمل بالمصلحة المرسلة:}

من خلال ما سبق من الكلام- في أقسام التكليفات- يتبين لنا أن مجال العمل العباء

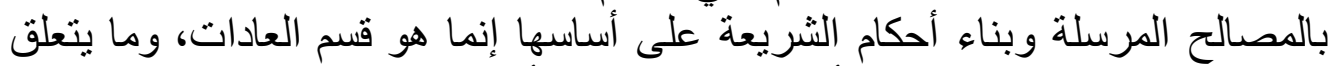

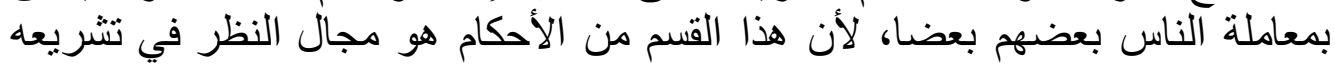
غلى المصالح، و عليه فلا دخل لها فيما كان قبيل العبادات.

ويلحق بالعبادات كل ما كان في معناها مما ليس للعقل سبيل إلى إدر الك المصلحة 


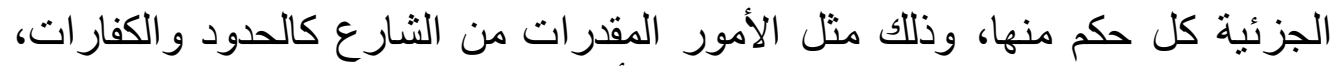

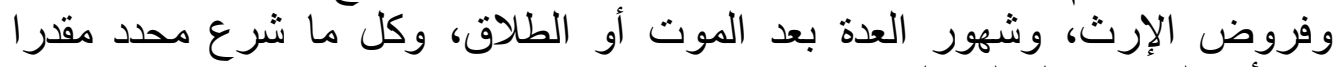
و استأثز الثنار ع بعلم المصلحة وفهر فيما حدد به.

ومن نافلة القول أن نؤكد:

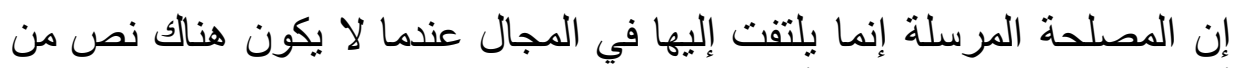

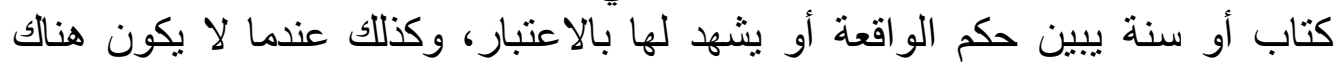

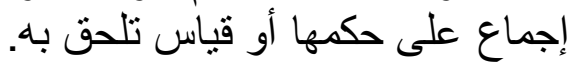

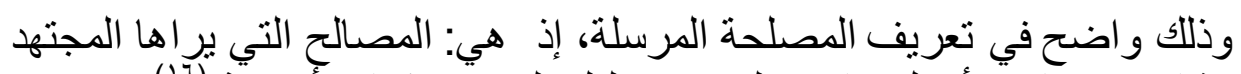

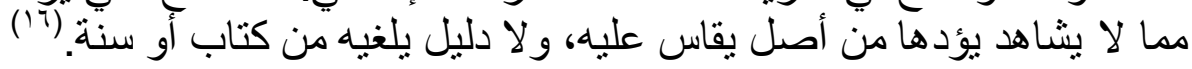

\section{الاستصلاح وأدلة القائلين به، والنافين له}

الأخذ بالمصلحة المرسلة هو ما يسمي في اصطلاح العلماء بـ"الاستصلاح".

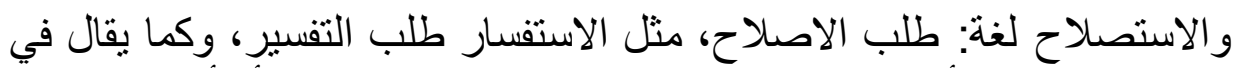

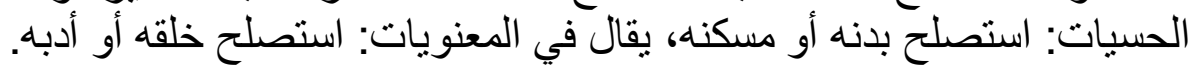

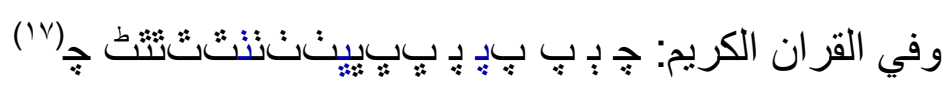

و أما في اصطلاح الاصوليين فهو: ترتيب الحكم الثر عي في واقعة لا نص فيها ولا إجماع، بناء على مر اعاة مصلحة مرسلة.

\section{حجية الاستصلاح:}

اتفق العملاء على أن المصلحة التي شهد لها الثرع بالاعتبار حجة، واتفقو ا على

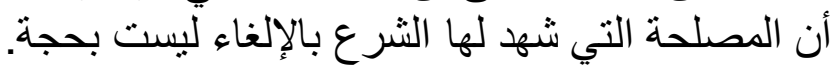
واختلفو افي المصلحة التي لم يشهد لها الثنارع بالاعتبار ولا إلغاء. وخلاصة مذاهب العلماء في القول بالاستصلاح نرجع إلى مذهبين: المذهب الأول: الاحتجاج بالاستصلاح دليلا شر عيا. (19) المذهب الثاني: عدم الاحتجاج بالاستصلاح ونفي كونه دليلا شرعيا. (r) 


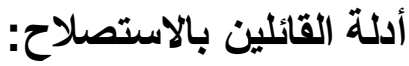

\section{احتج هؤلاء بأدلة عدة منها:}

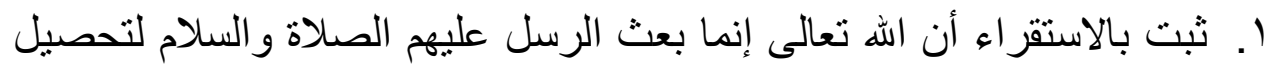

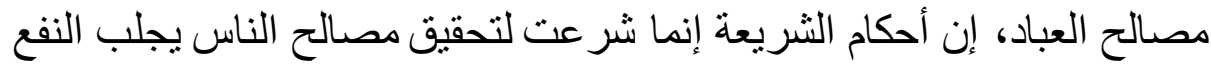

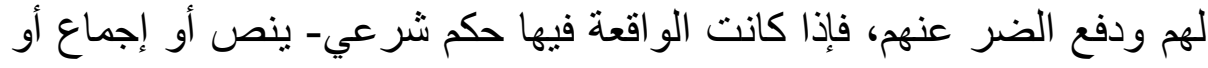

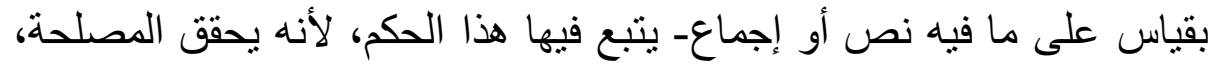

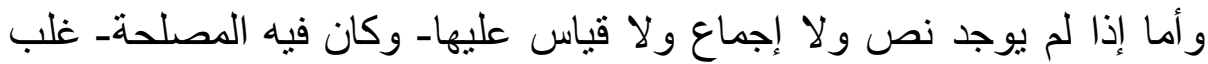
على الظن أنها مطلوبة للثنار ع، لأنه حيثما وجدت.

المصلحة الحقيقية فتم شرع الله، وتأخذ هذه الو اقعة حكما شرعيا، بناء على ما

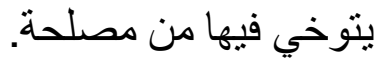

قال القر افي:(Y') لنا أن اله تعالى إنما بعث الرسل عليهم الصلاة و السلام لتحصيل

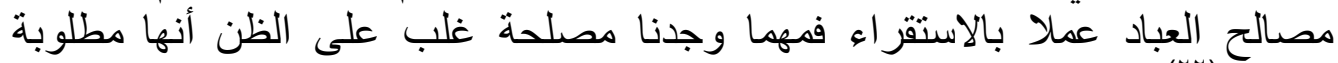

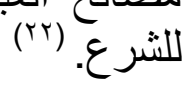

r. أن أصحاب النبي صلي الله عليه وسلم عملوا أمورا كثيرة لم يتقام لها شاهد الأدي

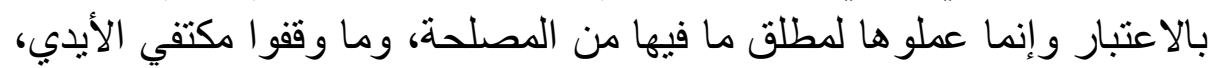

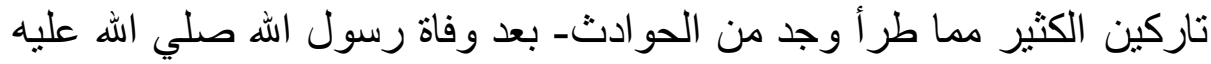

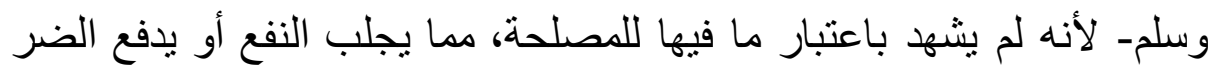

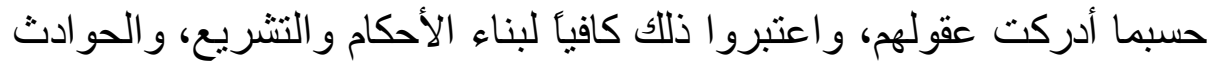
في ذللك كثيرة ومشهورة.

قال القر افي: ومما يؤكد العمل بالمصلحة المرسلة أن الصحابة رضوان الهاب اله عليهم

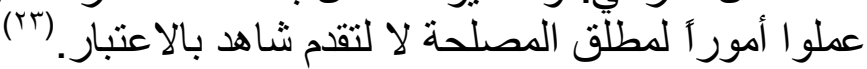

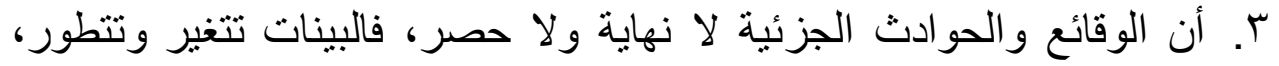

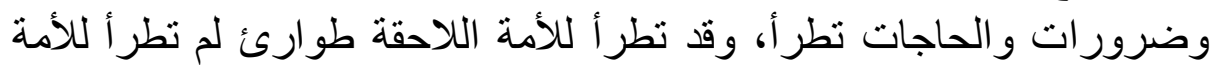

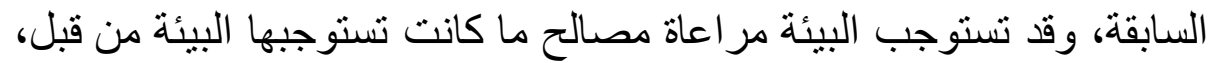

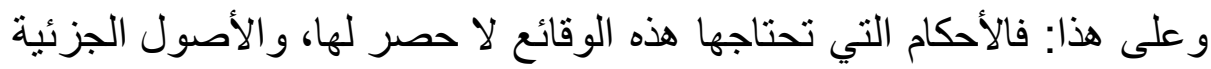

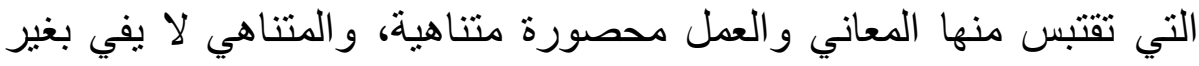


المتناهي، فلابد إذن من طريق أخر يتوصل بها إلى إثبات الأحكام الجزئية،

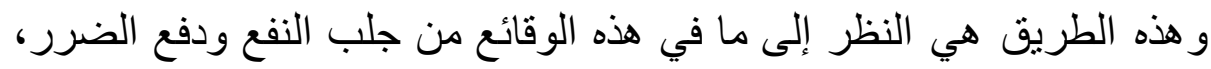

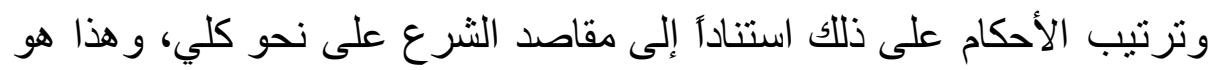

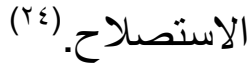

وكذلك قد بؤدي تغيير أخلاق الناس وذممهم وأحوالهح إلى أن بصير مفسدة ما بالها

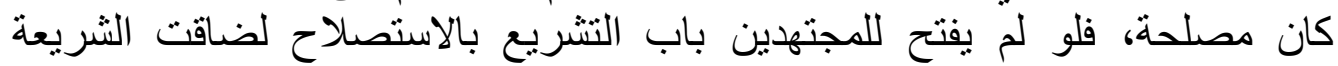

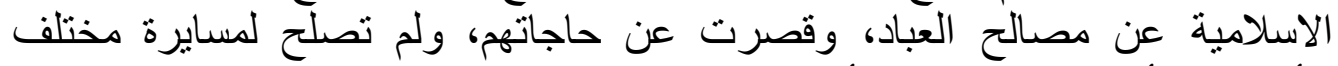

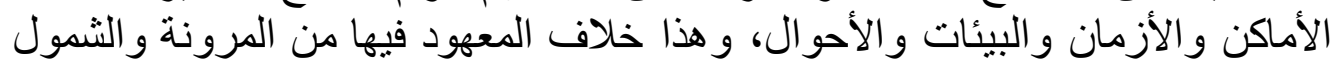

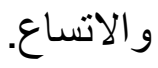

ع. أن مجال العمل بالاستصلاح إنما هو في المعاملات، ونحو ها مما هو من قبيل

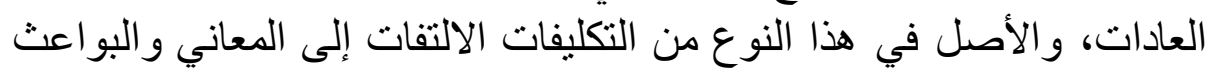
التي شرعت من أجلها الأحكام باتفاق الفقهاء.

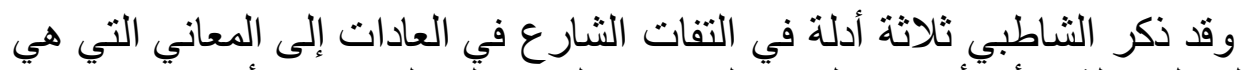

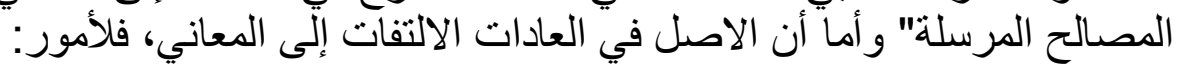

أولها: الاستقر اء: فإنا وجدنا الثار ع قاصدَ لمصالح العباد، ةالأحكام العادية تدور

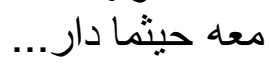

و الثاني: أن الثارع توسع في بيان العلل و الحكم في تشريع باب العادات... والثالث: أن الالتفات إلى المعاني قد كان معلوما في الفترات، وأعتمد عليه

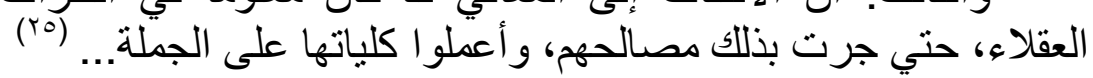

ولقد استدل الرازي(بr) في المحصول على وجوب القطع بكون الاستصلاح

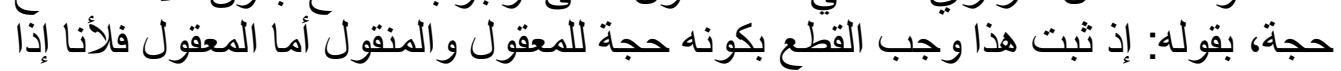

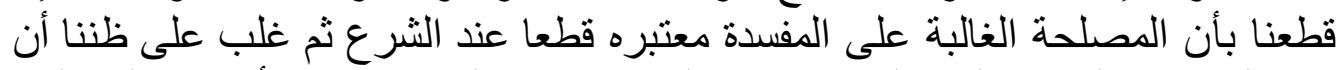

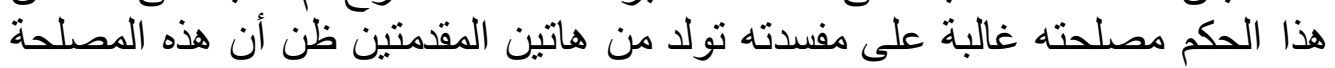

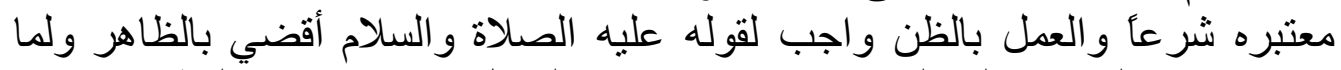

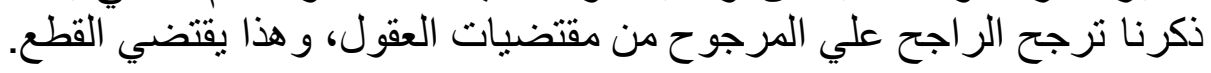

بكونه حجة وأما المنقول فالنص و الإجماع أما النص فقو له تعالى: جه وورو ج. (rV) 


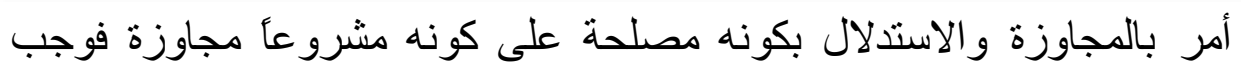

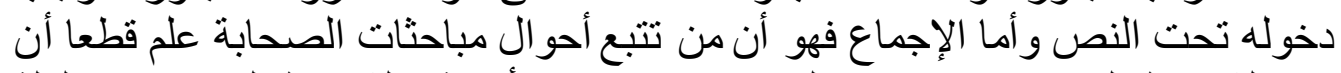

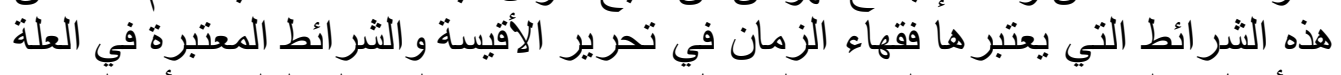

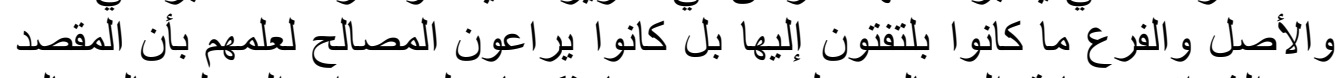

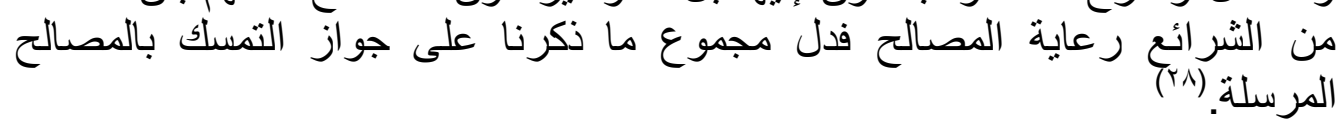

و الظاهر أن المراد بالجواز ليس على ظاهره، لأنه ذكر الوجوب قبل الاستدلال

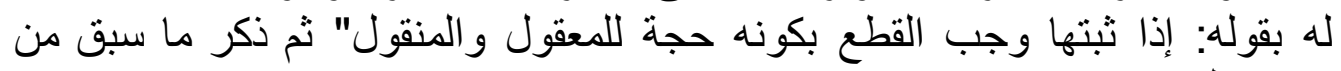

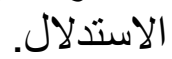

أدلة النافين للاستصلاح: استدلوا بأدلة منها: - إن

ا. أن الله سبحانه وتعالى لم يترك الناس سدي، من غير أن يشرع لهم ما يكفل

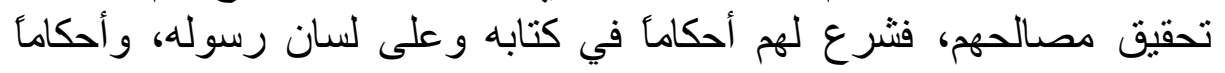

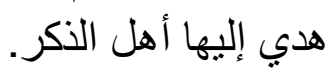

و العلم فلم يختلفو ا فيها، وأرشدهم إلى أنهم إن تناز عو ا في شيء فيه فيه حكم لله و لا إله

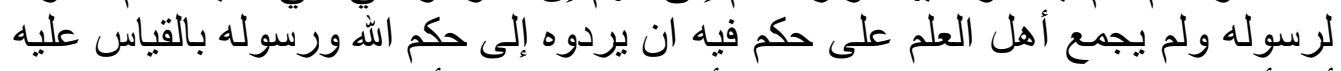

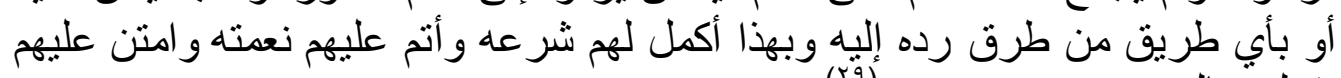

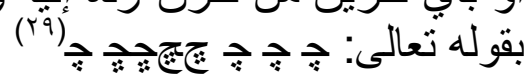

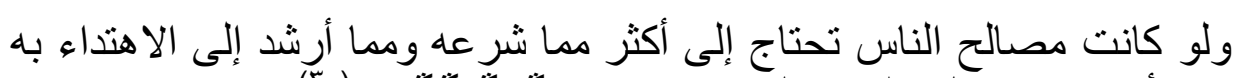

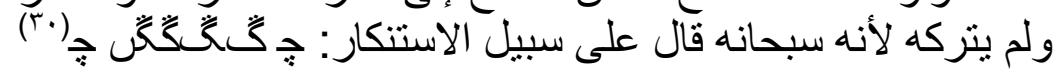

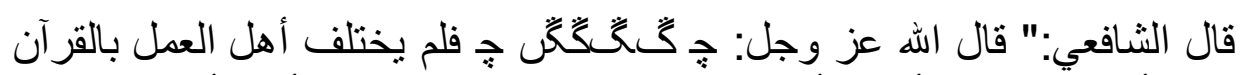

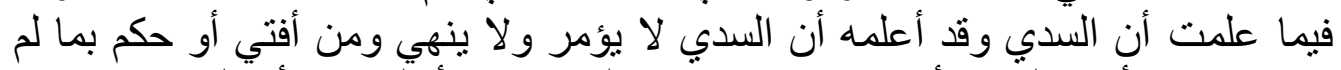

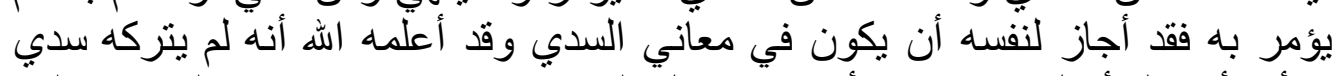

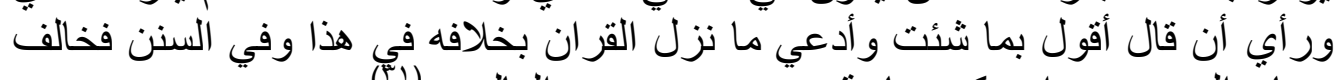

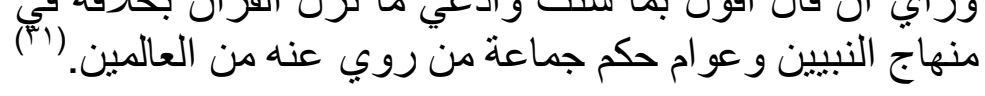

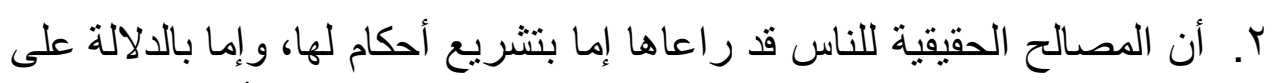

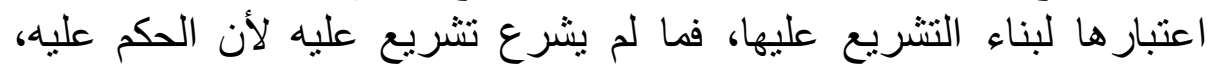


و الاستصلاح هو حكم مبني على مصلحة، لم يعتبر ها الثنارع فهو ليس بحكم شر عي.

قال الآمدي(r؟r): فالمصالح على ما بينا منقسمة إلى عهد من الثنارع اعتبار ها،

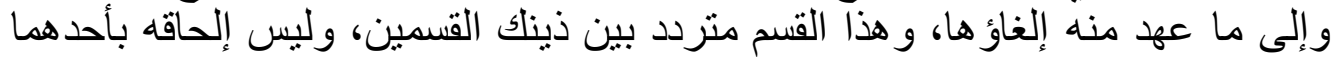

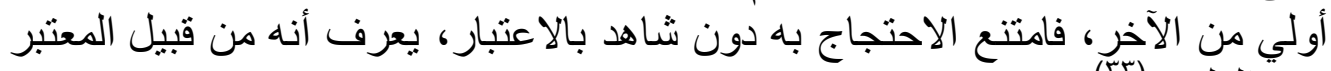

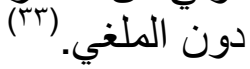

r. أن المصلحة المرسلة أي المطلقة عن دليل اعتبار ودليل إلغاء هي مترددة بين

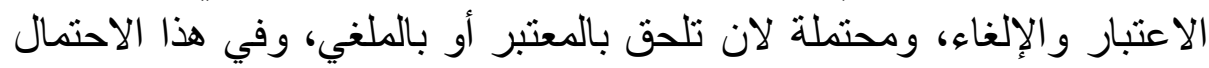

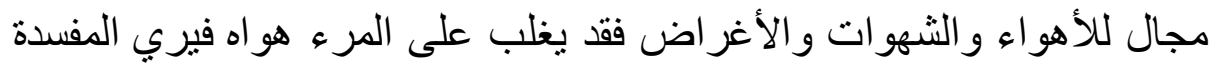

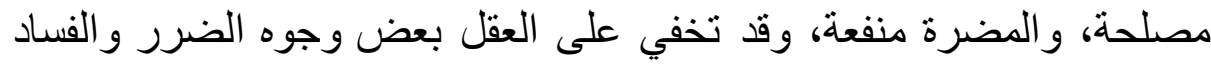

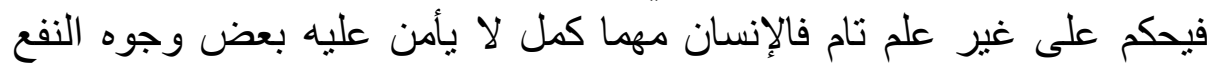

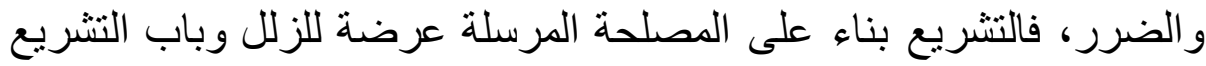

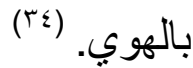

قال الزنجاني:" واحتجو ا في ذللك بأن الأصل أن لا يعمل بالظن لما فيه من خطر

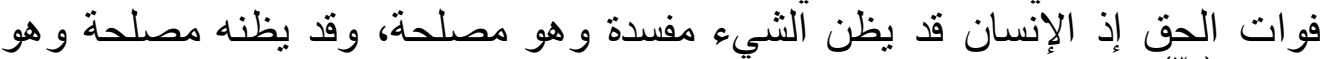
مفسدة. (ب0) 


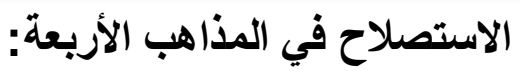

الاستصلاح عند المالكية: - n

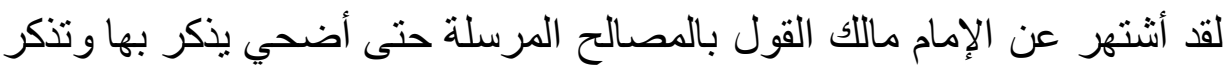

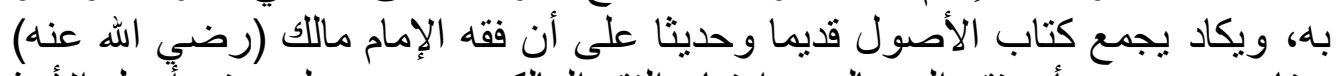

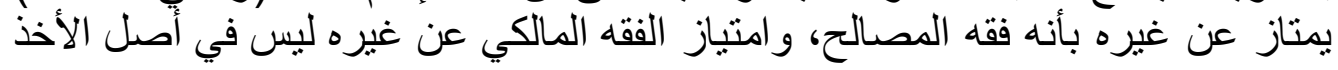

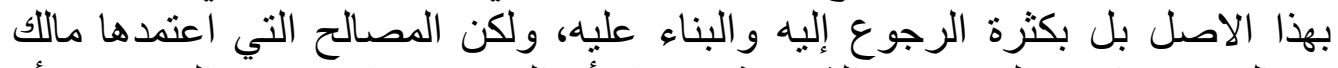

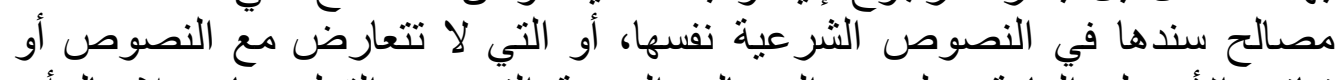

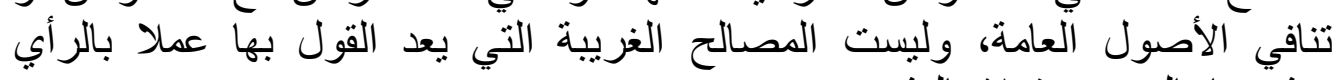
و تنتريعا بالهوي، وقول العال بالتشهي.

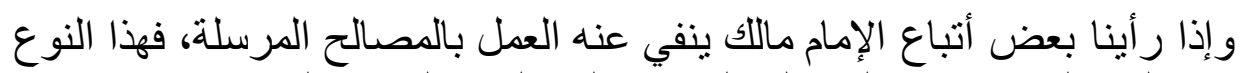

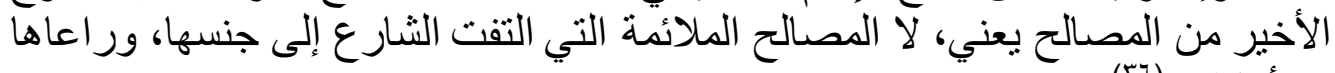

في أحكامه. (1")

\section{الاستصلاح في المذاهب الثلاثة:}

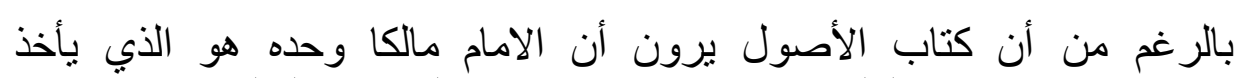

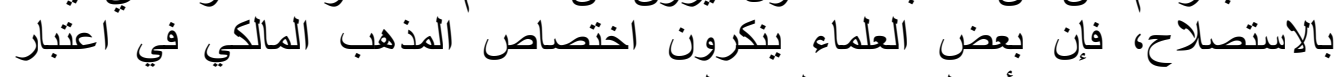

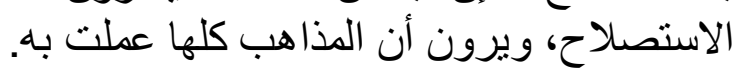

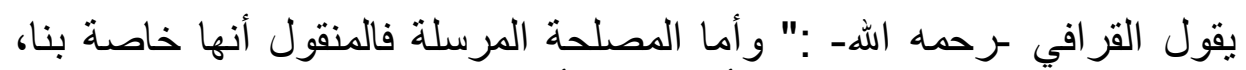

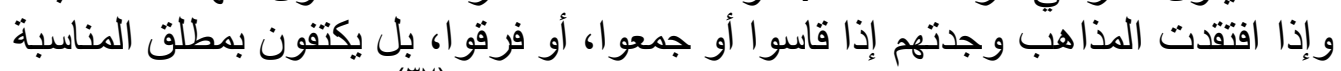

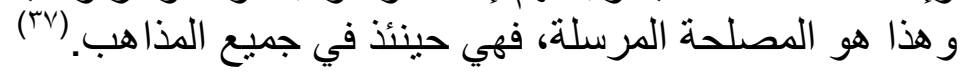

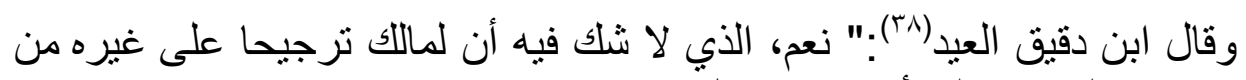

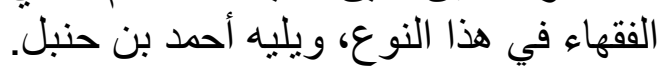
ولا يكاد يخلو غير هما عن اعتباره في الجملة، ولكن لهذين ترجيح في الاستعمال

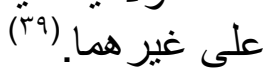

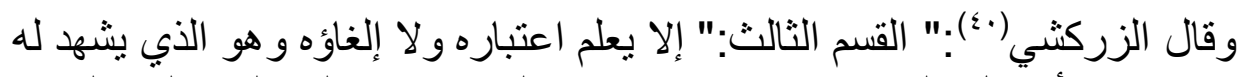

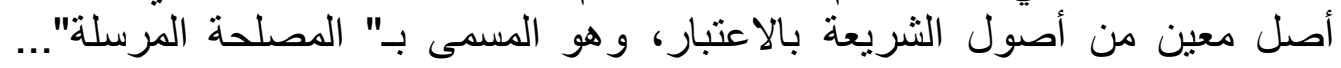

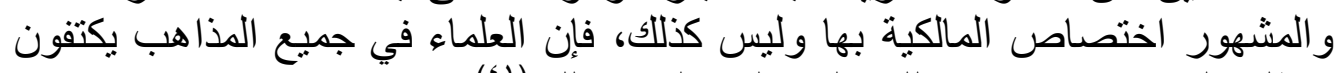

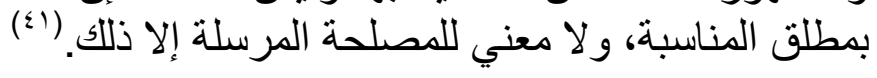


و المتتبع لفقه المذاهب الثناثة- غير المذهب المالكي- يجد ما بدل على أن المذاهب

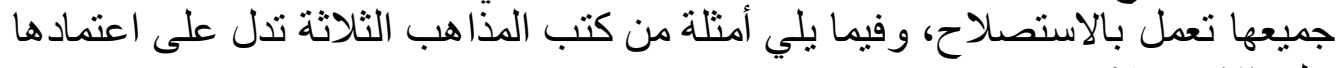
على الاستصلاح.

\section{الاستصلاح في المذهب الحنفي:}

يقول الثيخ عبد الو هاب في كتابه مصادر التشريع:" أم الحنفية فالمشهور في بعض الكتب أنهم لا يأخذون بالاستصلاح و لا بعتبرونه دليلا شر عياً.

\section{وهذا فيه نظر من عدة وجوه:}

أولها: أن فقهاء العراق في مقدمة القائلين بأن أحكام الشرع مقصود بها المصالح ومبنية

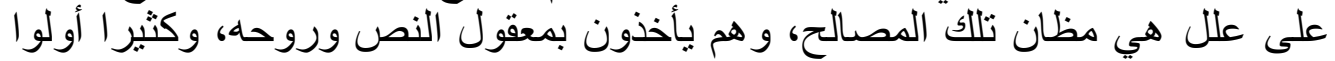

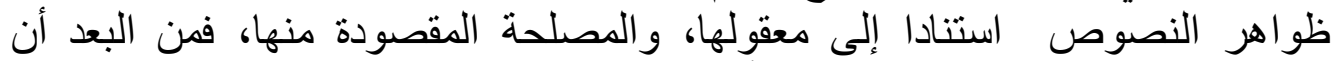

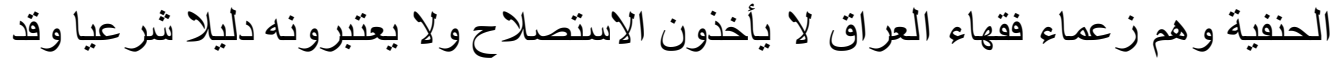

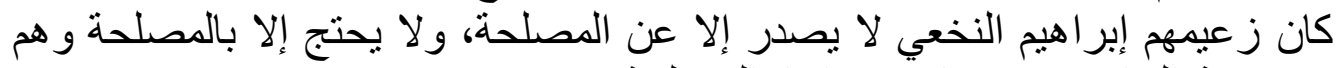

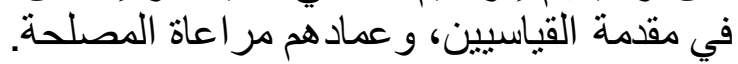

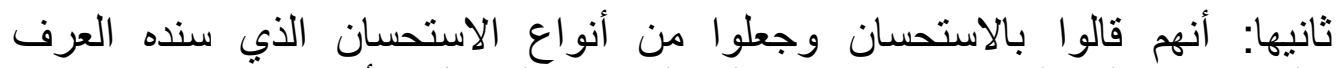

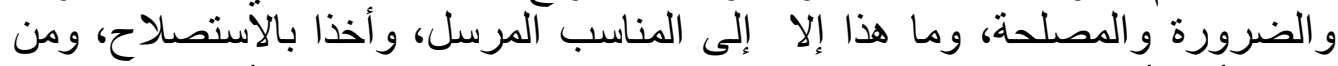

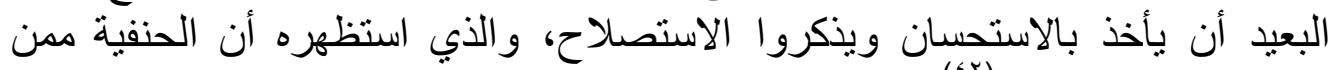
يحتجون بالاستصلاح.

و إذا قلنا إن الحنفية يحتجون بالاستصلاح فهم لا يعتبرونه دليلا مستقلا، و إنما يدخل عندهم ضمن أهم الأدلة التي امتاز بها فقهمح كالاستحسان و العرف كما أنثار إليه الأستاذ خلاف عذ ف

والذي يدل على دخول الاستصلاح في الاستحسان: تعريف بعضهم له بأنه:

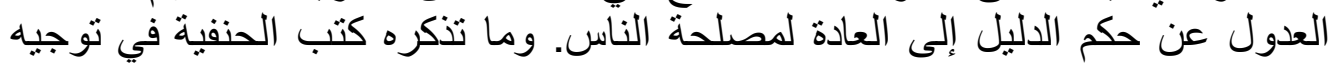

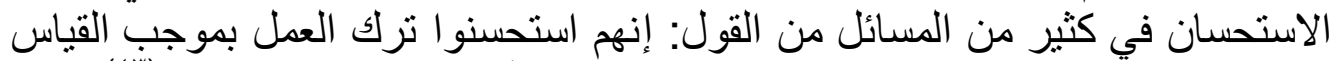

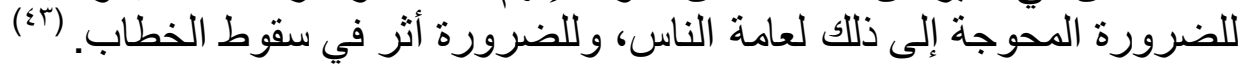

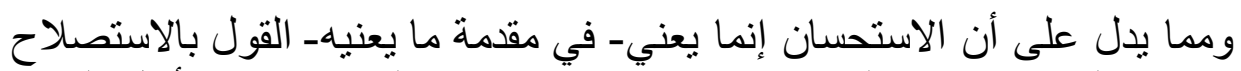

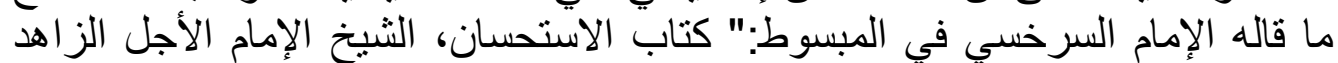

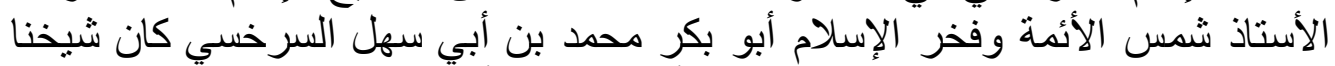

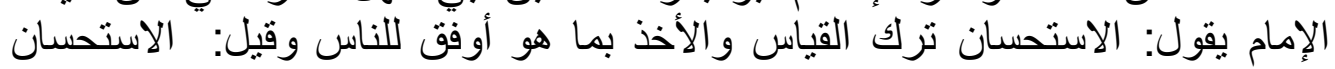




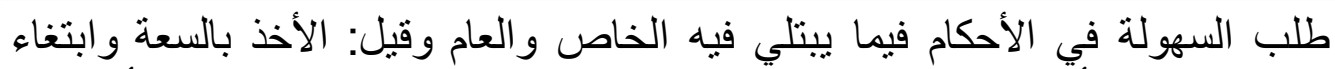

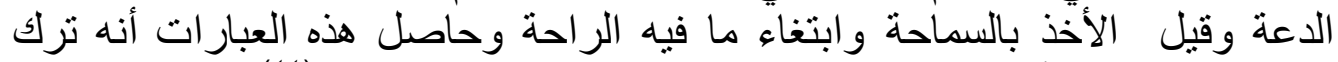

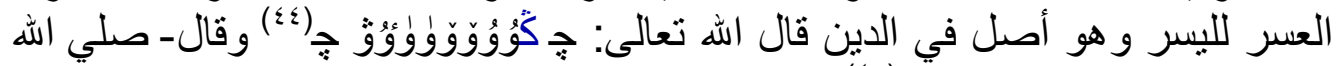

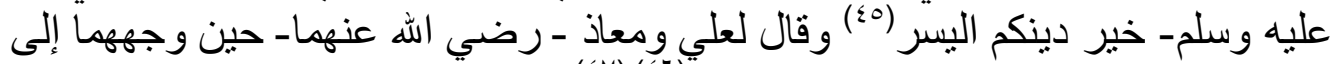

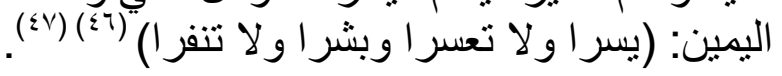

وبناء على هذا فقد خرجت معظم الأحكام التي أخذ بها بعض الأئمة استصلاحا

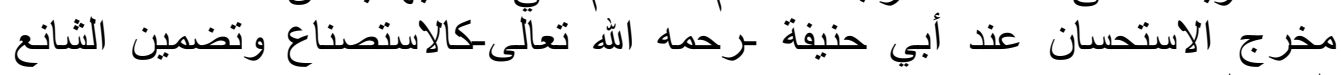
المشترك و غير ها.

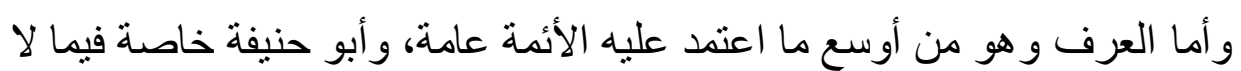

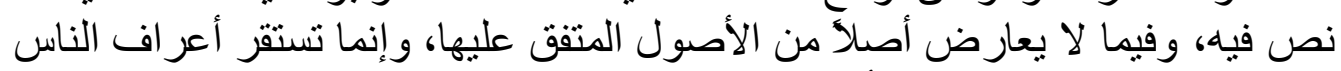

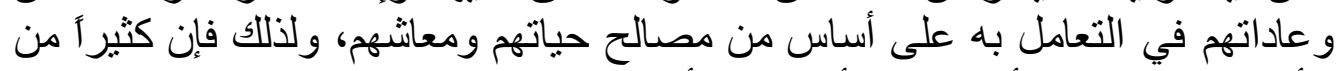

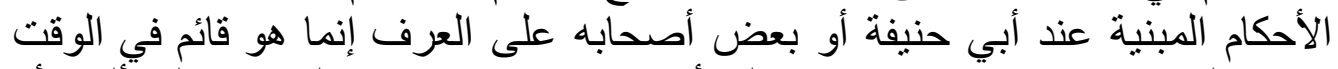

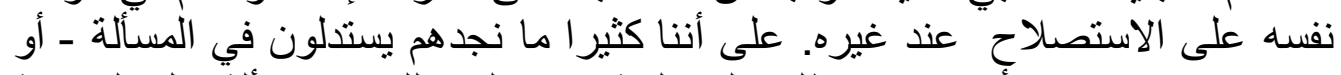

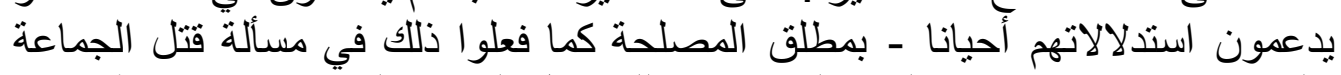

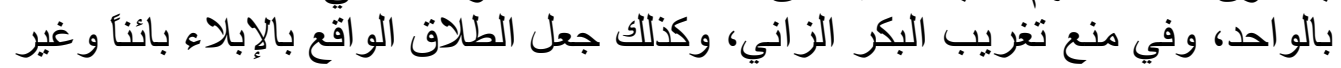
ذلك من الفروع.

أمثلة من الفقه الحنفي على عملهم بالاستصلاح:

\section{أ- عقد الاستصناع:}

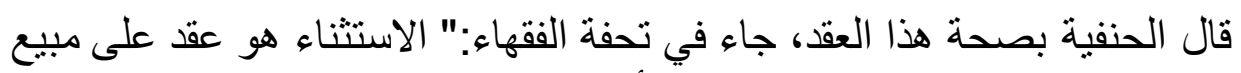

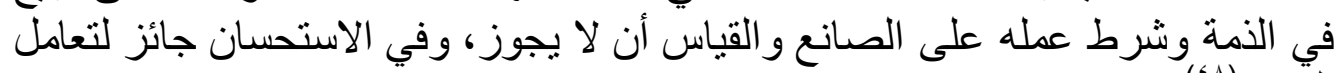

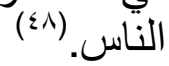

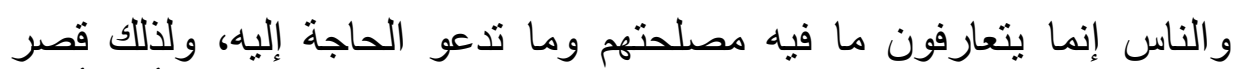

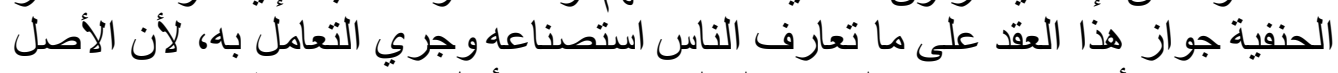

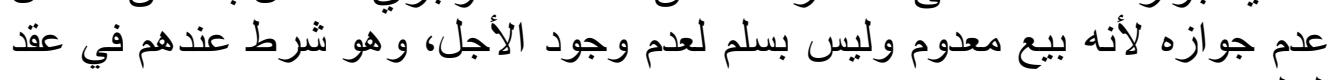
السلم.

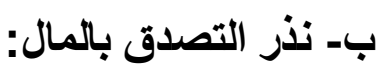

ذهب أبو حنيفة وأصحابه- رحمه الله تعالى- إلا أن من قال: مالي في المساكين

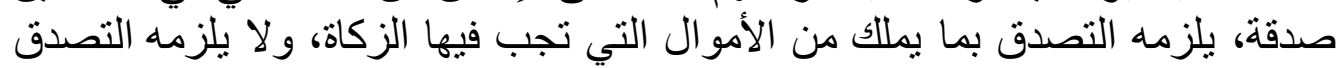


من مختلف الأموال، قال في الهداية: "ومن قال مالي في المسكين صدقة فهو على

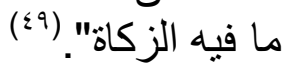

وقال في شرح فتح القدير:" الأصل فيما إذا قال مالي صدقة فقال في القياس

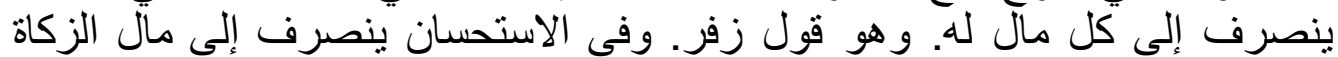
خاصة. (0.)

وذللك نظر إلى أنه لو لم يمسك ما عدا الزكوي من أمواله لاحتاج إلى أن بسأل الناس، ولا يحسن أن يتصدق بماله ثم بسأل الناس.

\section{ج- تغريب الزاني البكر:}

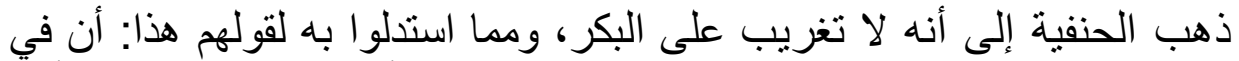

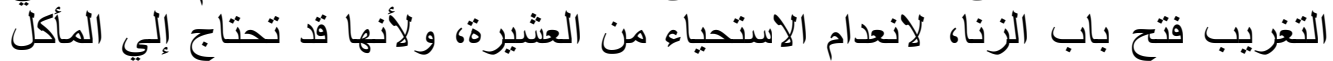

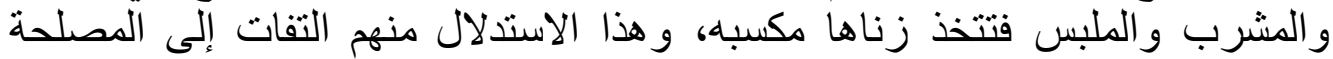

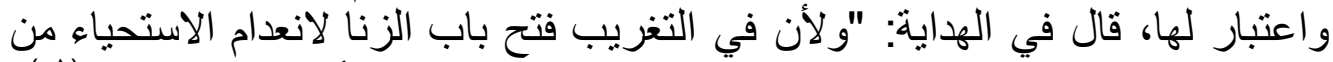

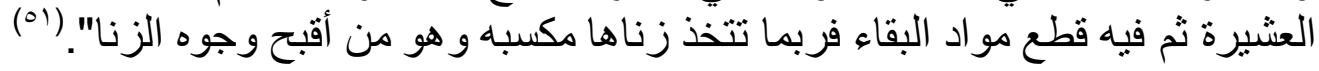

\section{الاستصلاح في فقه المذهب الثافعي:}

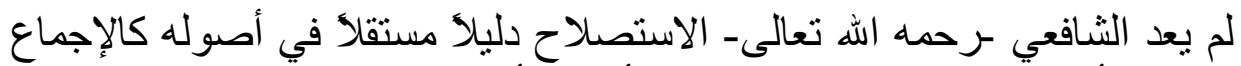
و القياس، ومن أجل هذا ظن كثير من الباحثين أنه لم يأخذ بهاه، ولم يعتبر الصالح الحئل المرسلة مستندا في اجتهاده.

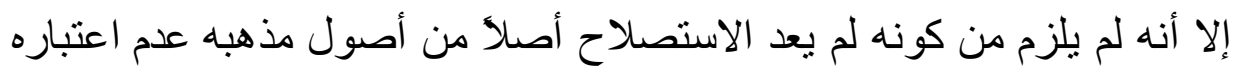

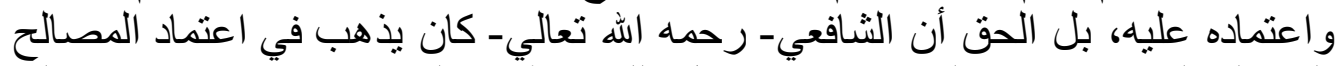

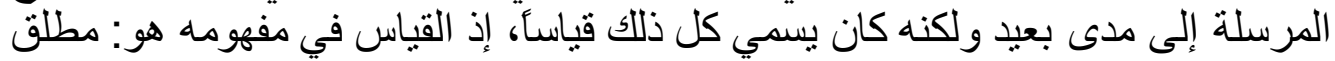

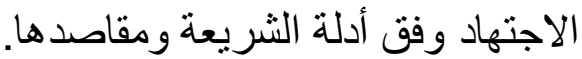

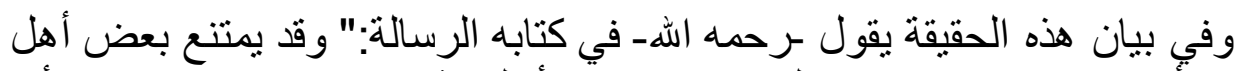

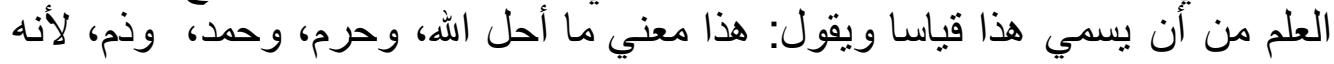
داخل في جملته، فهو بعينه، ولا قياس على ونى غيره. 


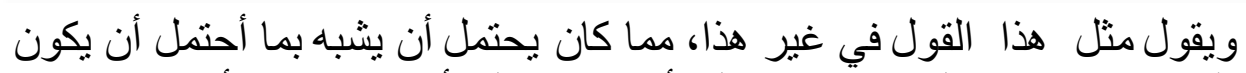

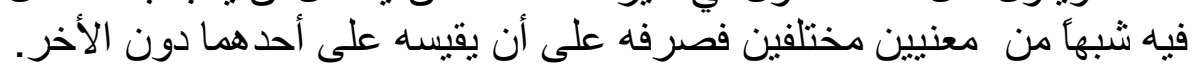
ويقول غير هم من أهل العلم ماعدا النص من الكتاب أو السنة فكان في معناه فهو قياس والله أعلم. ويقول في مكان آخر: "فالاجتهاد أبداً لا يكون إلا على طلب شيء، وطلب الثيء

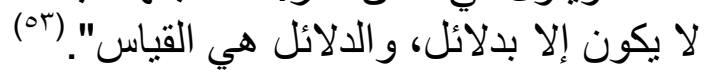

وقد نقل إمام الحرمين في كتابه البرهان عن الثافعي اعتماده على المصالح

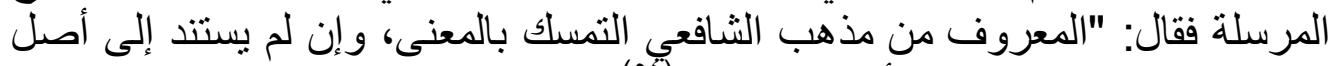

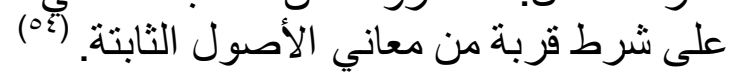

ثم بين مستنده في ذلك في ختام كلامه: "ومن تتبع كلام الثافعي لم يره متعلقَ

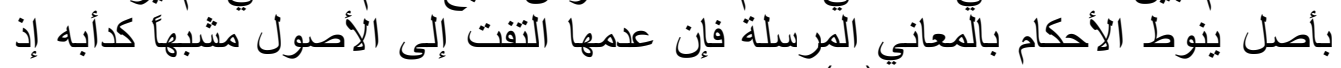

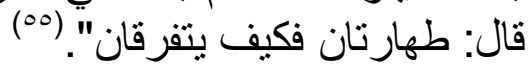

وقال الزنجاني(هo) تخريج الفروع على الأصول: "ذهب الثافعي ـرضي الله

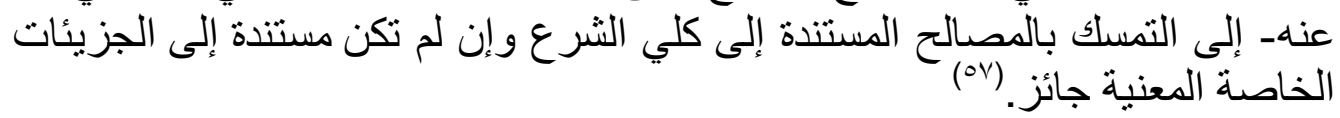

وذكر أمثلة على هذا، ثم قال: وأحتج في ذللك بأن الوقائع الجزئية لا نهاية لها

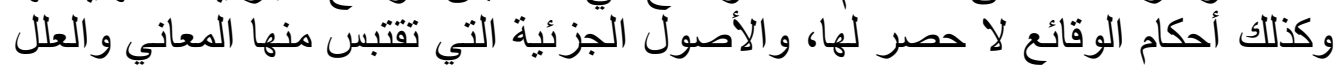

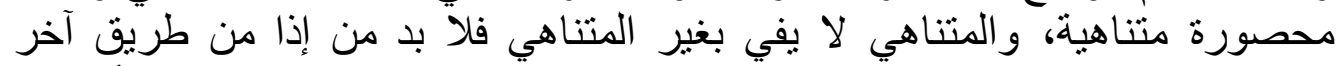

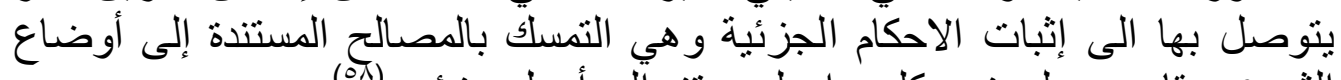

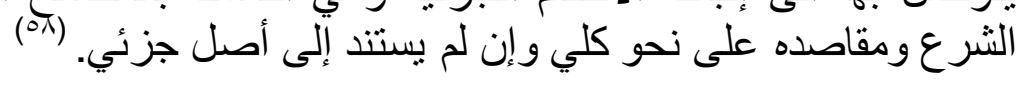
قال الرازي في المحصول ــبعد ذكره أنواع المصالح ودلائل اعتبار -: فدل

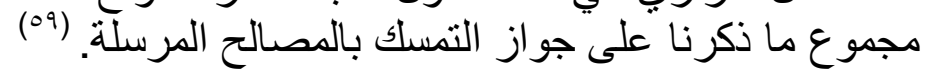

\section{أمثلة تطبيقية لاعتماد الشافعي رحمه الله تعالى- في اجتهاده على الاستصلاح:}

أـ ما جاء في الأم:" قال الثافعي- رحمه الله تعالىـ الرجوع عن الثهادات ضربان

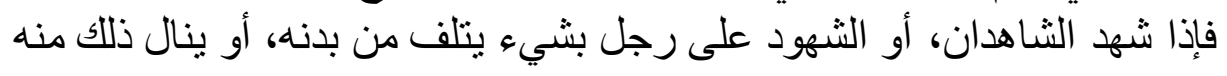


بشهادتنا فهي كالجناية عليه ما كان فيه من ذلك قصاص خير بين أن يقتص، أو أو يأخذ العقل وما لم يكن فيه من ذلك قصاص أخذ فئ فيه فيه العقل وعزروا دون

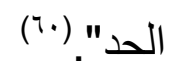

فقول الثافعي هذا لا يعتمد على دلالة نص من كتاب أو سنة، إذ ليس في شيء

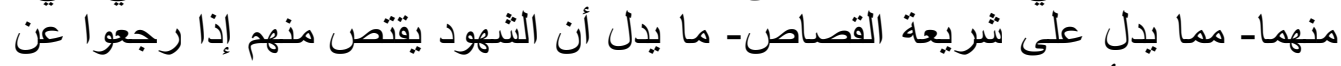

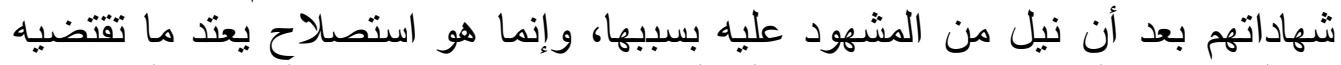

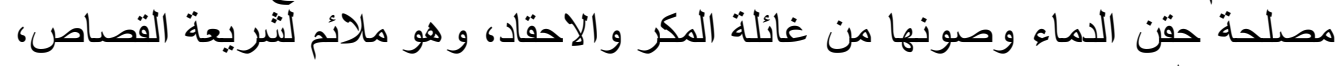
وإن كان الثافعي يسميه قياساء ولاه يسميه استصلاحا.

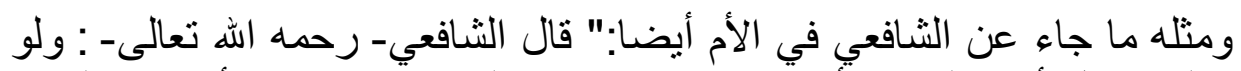

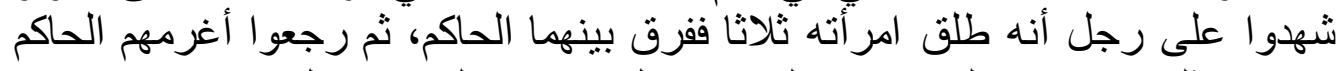

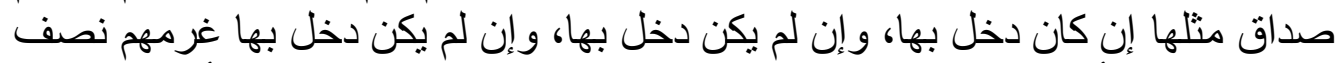

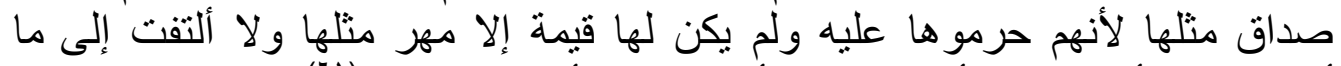

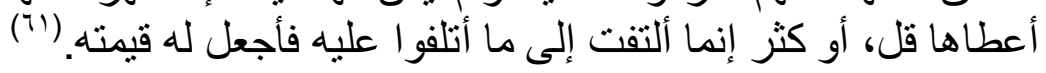

ب- ما ذكره الزنجاني بعد تقريره تمسك الثافعي بالمصالح المرسلة إلى كلي

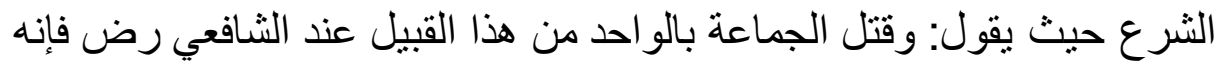

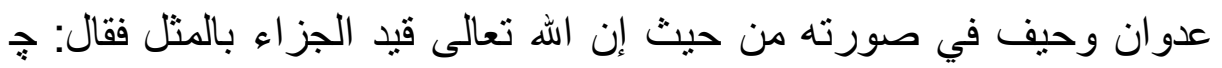

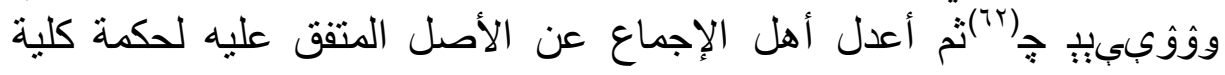

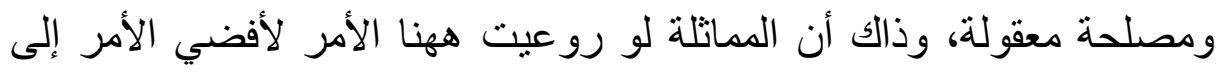

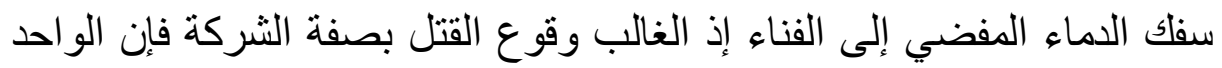

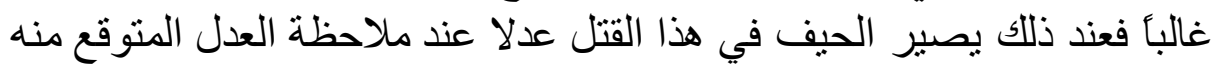

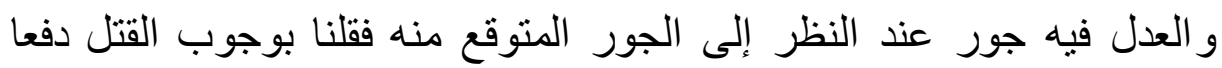

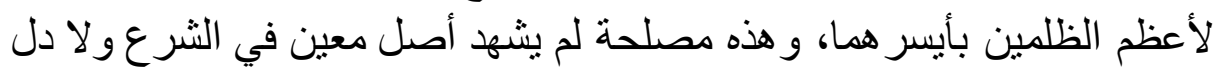
عليها نص كتاب و لا سنة.

بل هي مستندة إلى كلي وهاء وهو حفظ قانونه في حقن الدماء مبالغة في حسم مواد القتل و استبقاء جنس الأنس. (ii) وقال أيضا: فتفرع عن هذا الأصل أن القتل بالمثقل يوجب القصاص عند الثقاص الثافعي

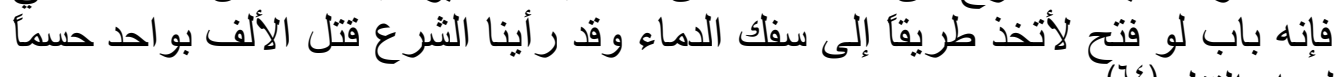

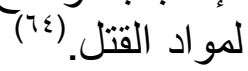




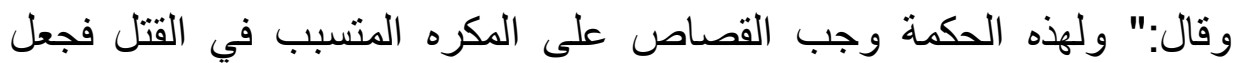

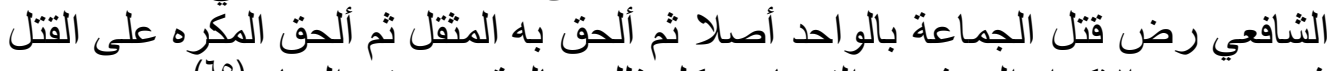
ثم تدرج من الإكر اه إلى شهود القصاص كل بل ذلك مبالغة في حقن الدماء. (70)

\section{الأستصلاح في المذهب الحنبلي:}

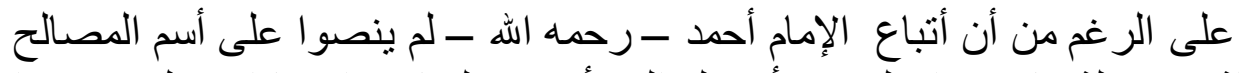

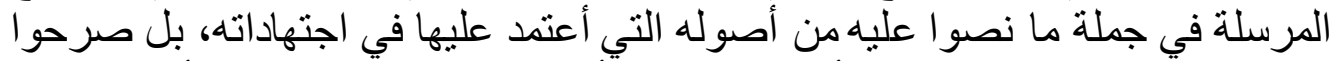

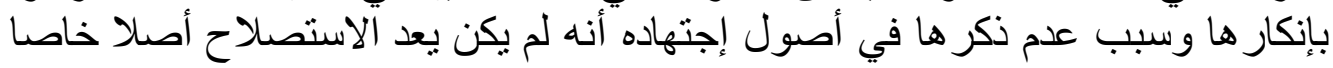
بل كان يعتبره معني من معاني القياس.

ومما يدل على أخذ أحمد وأصحابه بالاستصلاح ما نقله ابن القيم في كتابه إعلام

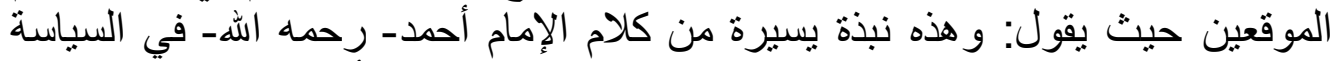

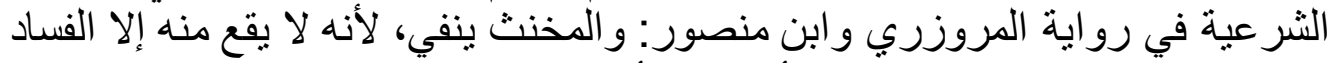

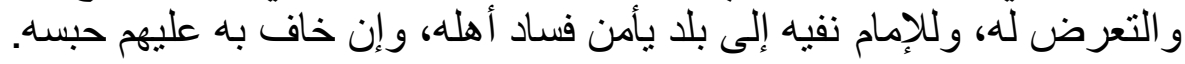

وقال في رواية حنبل، فيمن شرب خمرا في نهار رمضان، أو أتي شيئا نحو هذا:

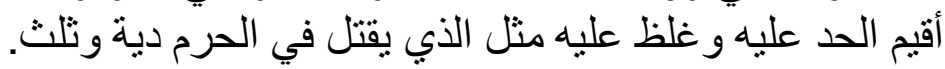
وقال في رواية حرب: إذا أتت المر أة تعاقبان وتؤدبان.

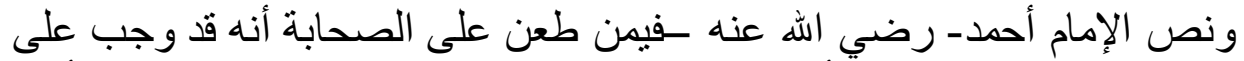

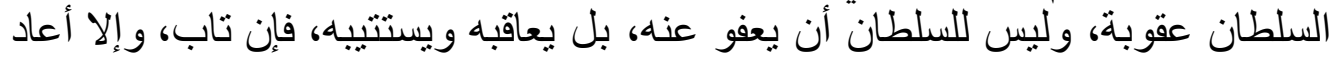
العقوبة.

وصرح أصحابنا في أن النساء إذا خيف عليهن المساحقة حرم خلوة بعضهن ببعض. وصرحوا بأن من أسلم وتحته أختان فإنه يجبر على اختيار احداهما، فأن أبي ضرب حتى يختار. قالو ا: و هكذا كل من وجب عليه حق فامتنع من أدانة، فإنه يضرب حنى يؤديبه. (7T) 


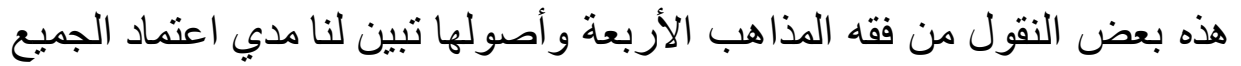

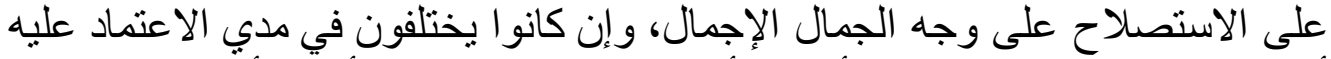

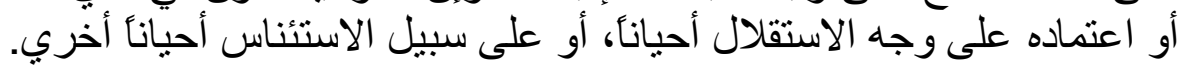

\section{أثز الاختلاف في الاستصلاح في فقه المعاملات}

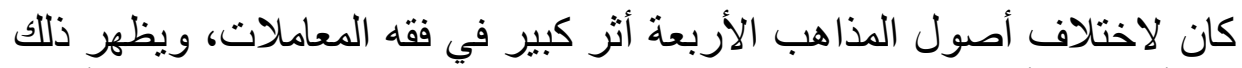

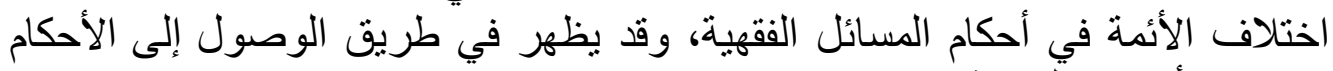
تساوت الأحكام و النتيجة.

و الإمام الذي اعتمد على أصل معين واعتبره دليلا مستقلا نظر المسائل الفقهية

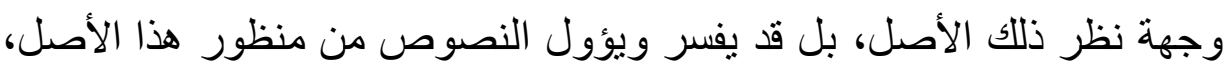
وفيما يلي نذكر بعضا من تللك المسائل الفقهية في المعاملات، على سبيل الإنى المثنال لا

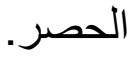

المسألة الأولي: ضمان المبيع قبل القبض:

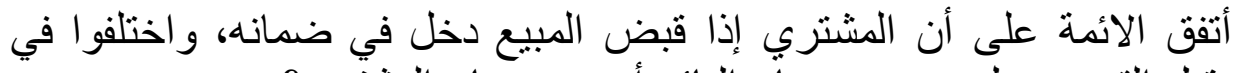
ضمانه قبل القبض: هل هو من ضمان البائع أو من ضمان المن المنتري؟

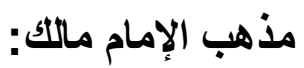

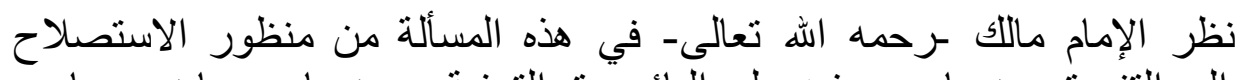
فذهب إلى التقريق بين ما يجب فيه على البائع حق التوفية، وبين ما هو حاضر هالهر وما هو غائب.

قال ابن رشد(YYT): وأما ماللك فله في ذلك تفصيل، وذلك أن المبيعات عنده في هذا

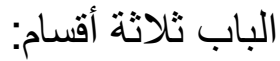

$$
\text { بيع يجب على البائع فيه حق توفية من وزن، أو كيل، و عدد. }
$$

وبيع ليس فيه حق توفية، و هو الجراف، أو لا يوزن، ولا يكال، ولا لا يعد، فأما ما

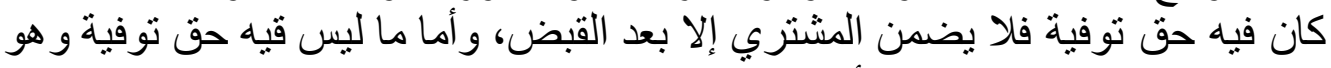

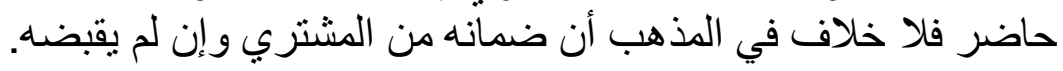




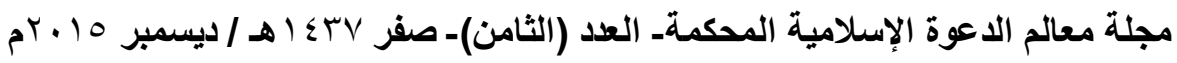

وأما المبيع: فعن مالك في ذلك ثلاث روايات :

أشهر ها: أن الضمان من البائع إلا أن يشترطه على المبتاع.

و الثانية: أنه من المبتاع، إلا أن يشترطه على البائع.

والثالثة: الفرق بين ما ليس بمأمون البقاء إلى وقت الاقتضاء كالحيوان

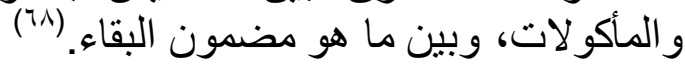

عمدة الإمام مالك : - مالك

و عمدة الإمام مالك في هذا الر أبي الاستصلاح، قال ابن رشد:" وتفريق مالك بين

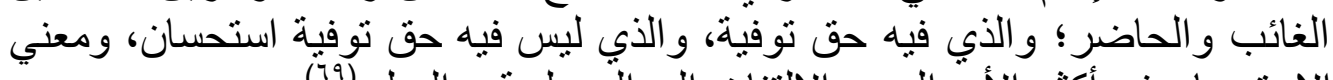

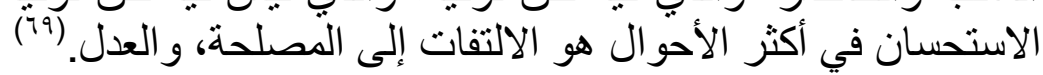

مذهب أبي حنيفة والشافعي:

و أما و أبو حنبفة والثافعي فلم يريا في هذه المسألة من منظور المصالح المرسلة.

فقد ذهب أبو حنيفة والثافعي إلى أن المبيع لا يدخل في ضمان المشتري حتى إنى

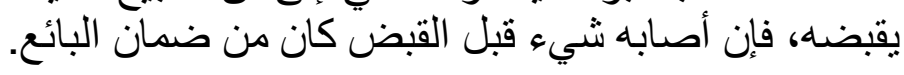

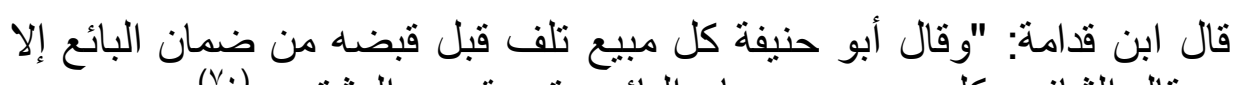

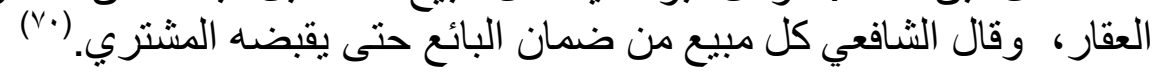

قال النووي في المنهاج: "المبيع قبل قبضه من ضمان البائع فإن تلف انفسخ البيع

وسقط الثن. (V) (V)

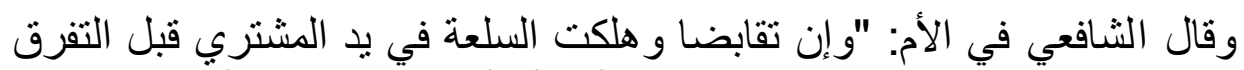

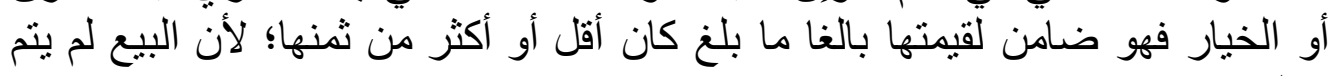

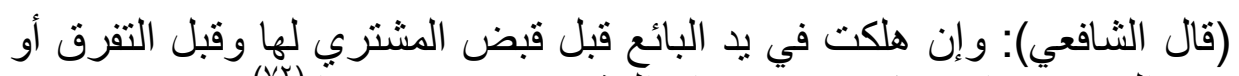

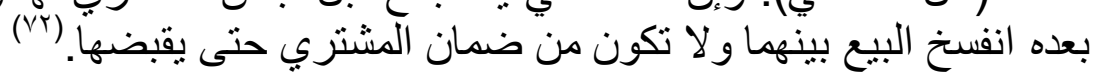

قال صحاب شرح فتح القدير: وما يسلم المبيع هو في ضمان البائع في جميع

زمان حبسه. 
واحتج الحنفية والشافعية في ذلك بالسنة والقياس والمعقول:

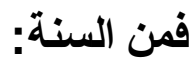

ا - حديث حكيم بن حزام أن النبي صلي الله عليه وسلم قال:" لا تتبع ما لم

تقبضهة"(Vo)(

r- حديث بن زيد بن ثابت أن النبي صلي الله عليه وسلم نهي أن أتباع السلع حيث

تباع حتى يحوز ها التجار إلى رحالهم.

"- حديث" من ابتاع طعامأ فلا يبعه حتى بستوفيه"، قال ابن عباس: ولا أحسب كل

شيء إلا مثله.

ع - حديث عتاب أسيد أن رسول الله عليه وسلم لما بعثه إلى مكة، قال له:" أنهم عن

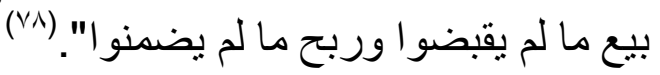

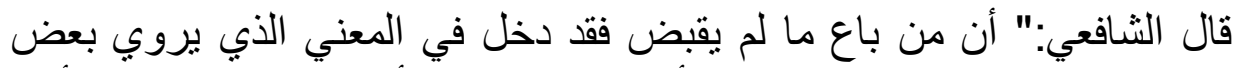

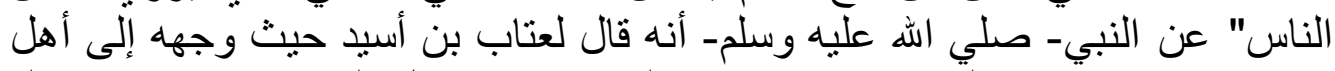

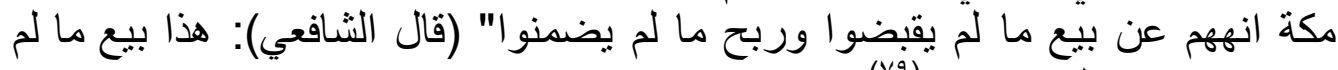

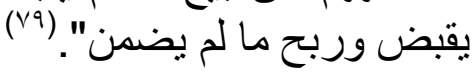

ومن القياس: قال النشافعي:" و هذا القياس على حديث النبي صلى الله عليه وسلم

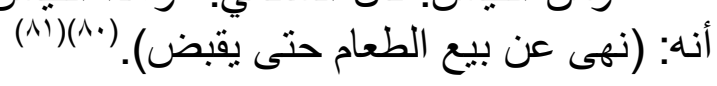

ومن المعقول: قال الثربيني: ولضعف الملك قبل القبض بدليل انفساخ العقد

بالتلف قبله.

\section{مذهب الإمام أحمد بن حنبل:}

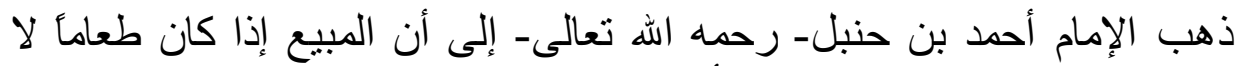

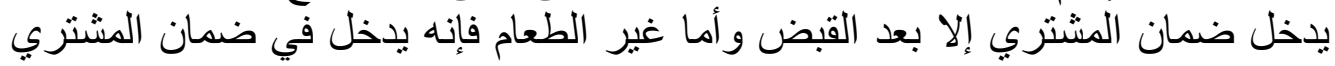

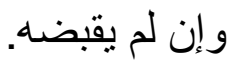


قال الخرقي:" و إذا وقع للبيع على مكيل، أو موزون، أو معدود، فتلف قبل قبضه فئه

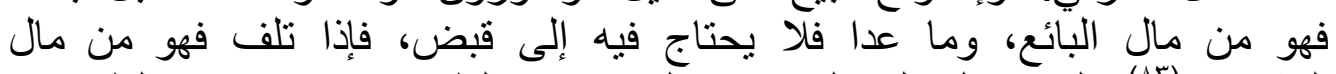

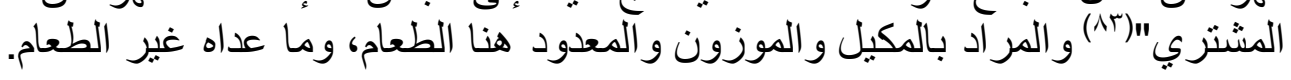
قال ابن قدامة:" ونقل عن أحمد، أن المطعوم لا يجوز بيعه قبل قبضها، سواء كاء كان

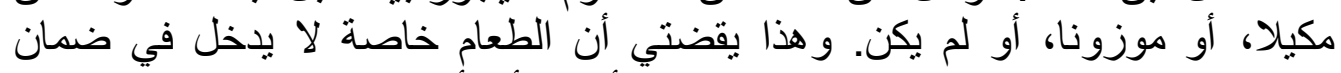

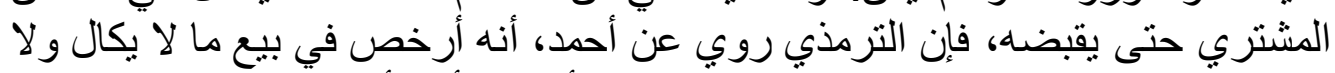

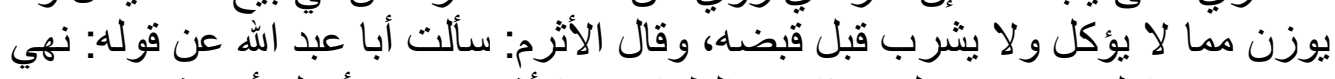

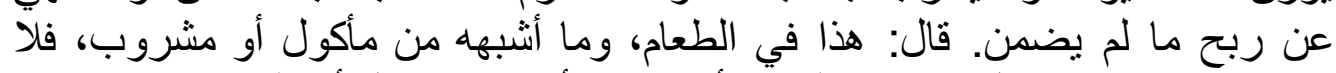

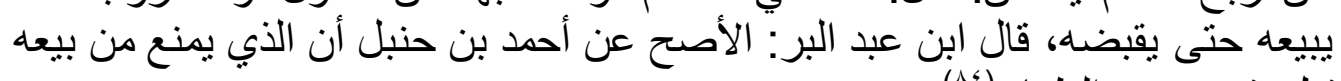

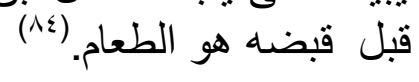
حجة الحنابلة: - 2 - مجلة استدلوا بعدة أدلة منها:

ا - أن النبي صلي الله عليه وسلم نهي عن بيع الطعام قبل قبضه، فمفومه إباحة بيع ما سو اء قبل قبضه.

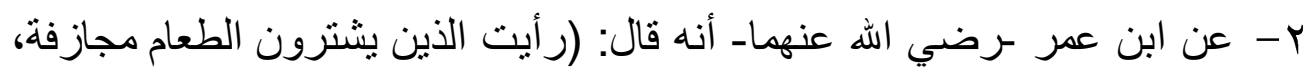

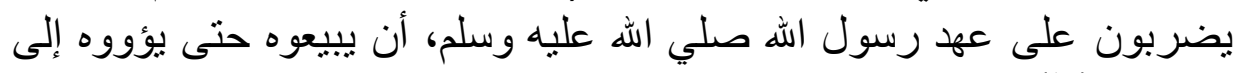

$$
\text { رحالهم). (^o) و هذا نص في في ريع المعين. }
$$

ب- عموم قوله عليه السلام:" من أبتاع طعاما فلا يبعه حتى يستوفيه". (T^)

ع - حديث ابن عمر قال: كنا نشتري الطعام من الركبان جز افأ فنهانا رسول الله صلي

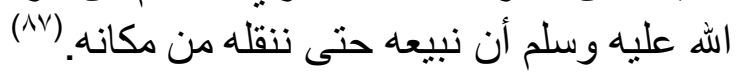

ه- واستدلو البالاجماع كما نقله ابن المنذر: أجمع أهل العلم على أن من أشتري

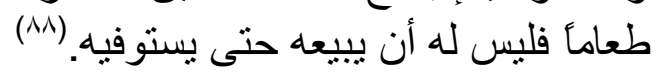
قال ابن قدامة: "وتخصيص النبي- صلي الله عليه وسلم- الطعام بالنهي عن بيعة قبل قبضه دليل على مخالفة غيره له". 
واستدل في ضمان المشتري في غير الطعام: بقوله صلى الله عليه وسلم:

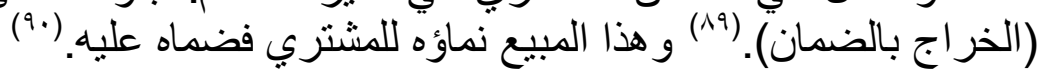

ويبدو لي أن الخلاف بين رأي الحنفية والثافعية، ورأي الحنابلة يعود إلى ديك

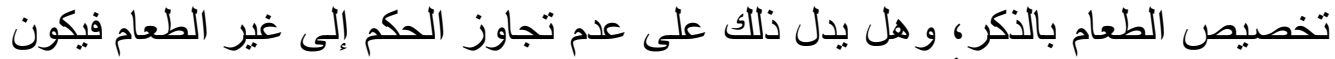

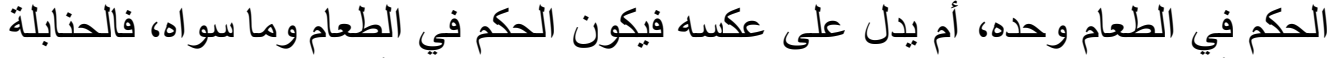
يرون أن الحكم خاص في الطعام، والحنفية والثافعية برون أنس أن الحكم في الطعام وفي غيره.

المسألة الثانية: ضمان الرهن في يد المرتهن:

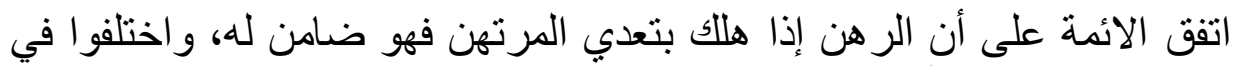

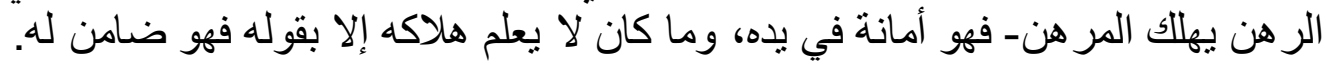

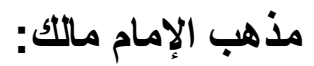

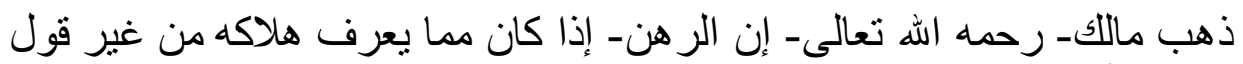

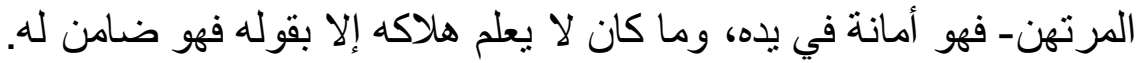

قال ابن رشد:" وفرق قوم بين ما لا يغاب عليه مثل الحيوان، و العقار مما لا

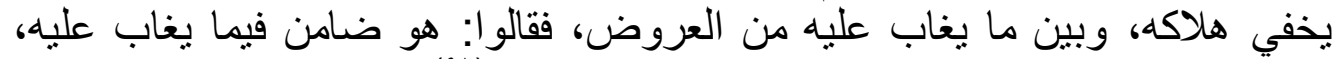

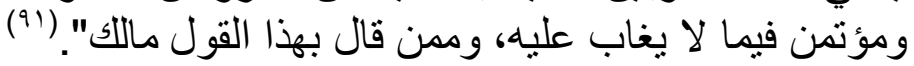
عمدة مالك- رحمه الله تعالىى:

عمدة الإمام مالك في هذه المسألة النظر المصلحي، ووجه المصلحة، أن أن التهمة تلحق فيما لا يعلم هلاكه، فيكون مضدونا، وها، ولا تلحق فيما يعلم هلاكه فيكون أمانة.

قال ابن رشد:" و أما تفريق ماللك بين ما يغاب عليه وبين ما لا يغاب عليه فهو

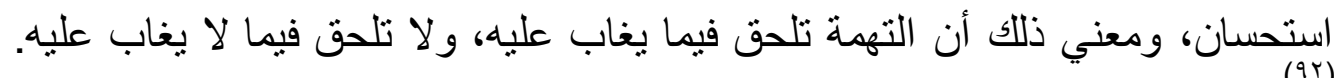

و قد ذكر ابن رشد في أكثر من موضع من كتابه أن المر اد بالاستحسان عند ماللك

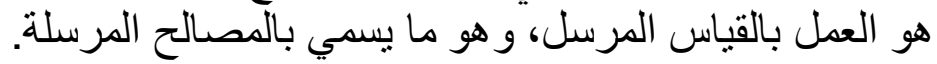


ذهب أبو حنيفة وأصحابه ـرحمه الله تعالى- إلى أن الرهن في يد المرتهن مضمون عليه بالأقل من قيمته ومن الدين. قال في بداية المبندي: "و إذا سلمه إليه فقبضه دخل في ضمانه ولا يصح الرهن

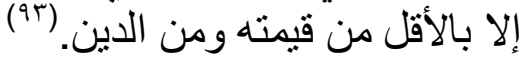

عمدة الحنفية في ذلك:

من السنة: قول النبي صلي الله عليه وسلم للمرتهن بعد ما نفق فرس الرهن هن عنده:

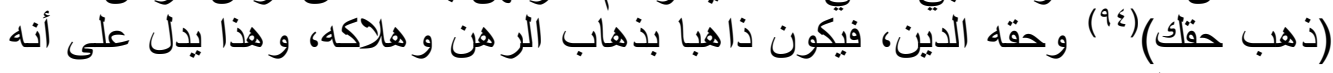
مضدون عليه.

وقوله صلي الله عليه وسلم: (إذا عمي الر هن فهو بما فيه) معناه على ما قالو ا: إذا

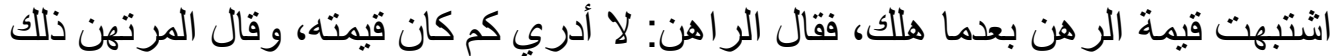

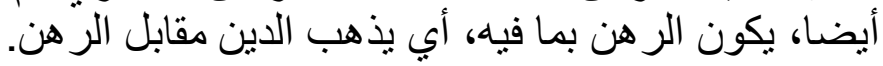

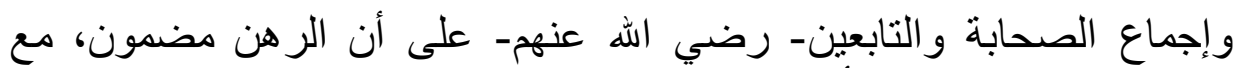

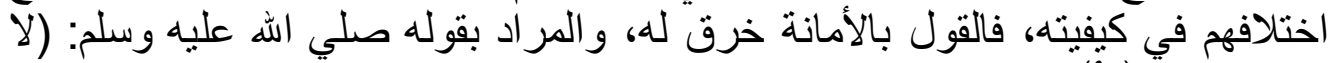

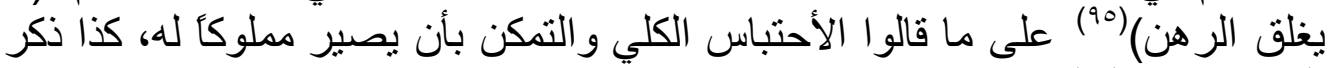
الكرخي عن السلف.

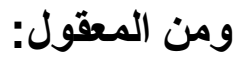

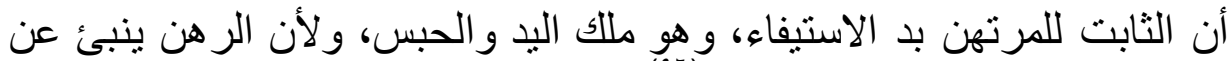

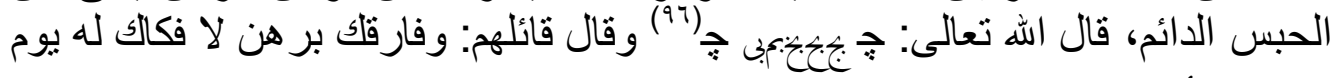

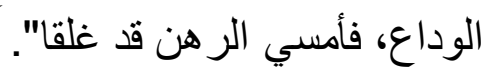
و الأحكام الثر عية تنعطف على الألفاظ على وفق الأنباء. ولأن الرهن وثيقة لجانب الاستيفاء، وهو أن تكون موصلة إليه، وذللك ثابت له اله

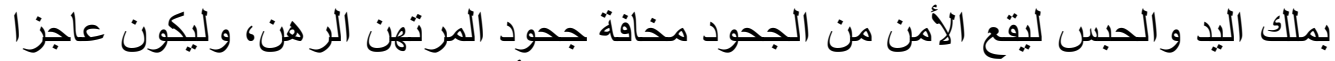

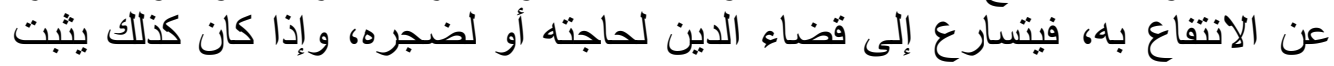

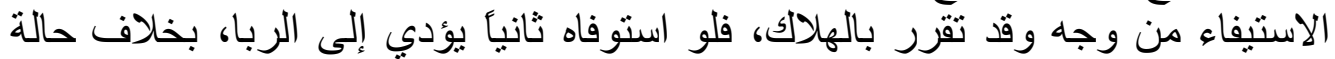

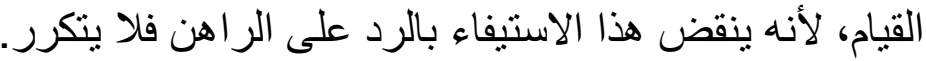


ولا وجه إلى استيفاء الباقي بدونه؛ لأنه لا يتصور، و الاستيفاء يقع بالمالية أما

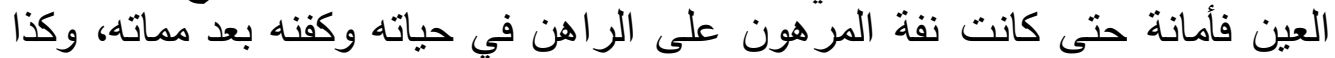

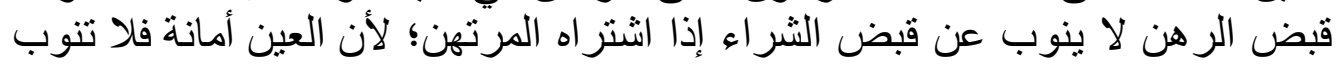

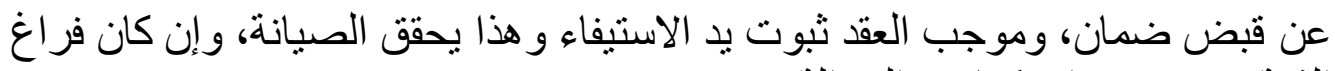
الذمة من ضرور اته كما في الحوالة وحن الته

فالحاصل: أن عندنا حكم الر هن صيرورة الرهن هن محتبسا بدينه بإثبات بد الاستيفاء

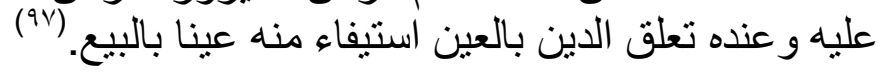

\section{مذهب الإمام الشافعي وأحمد بن حنبل:}

ذهب الثافعي وأحمد- رحمهما الله تعالى- إلى أن الرهن هألى أمانة في يد المرتهن،

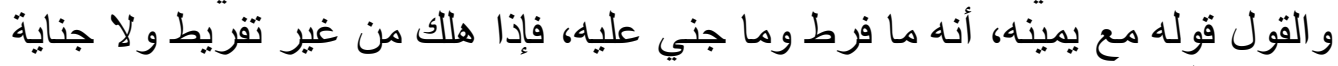
فهو من الراهن.

قال في الأم: فإذا رهن الرجل الرجل فقبضه المرتهن فهلك في بد الرهن هن في يدي

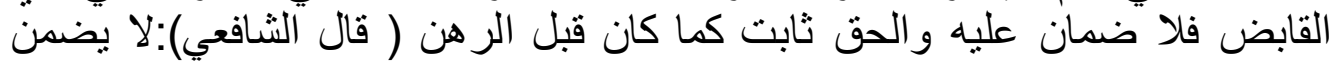

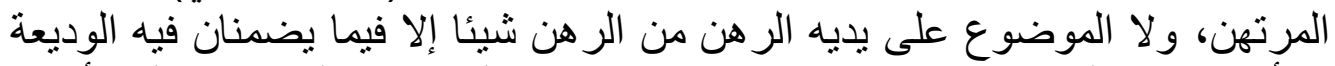

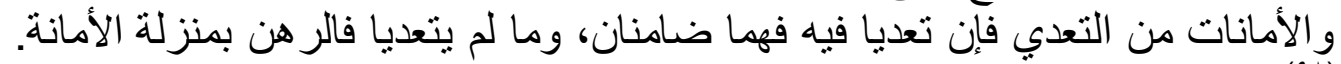

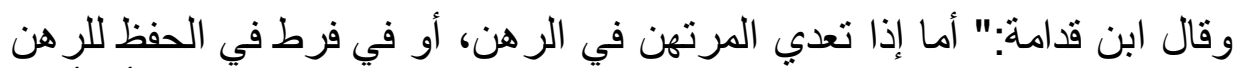

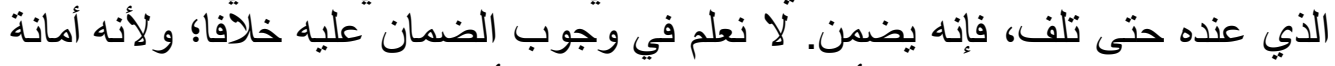

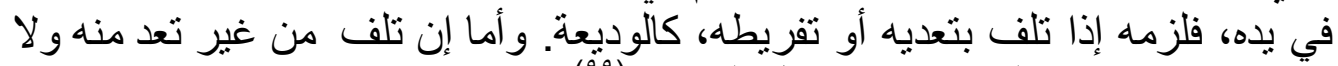

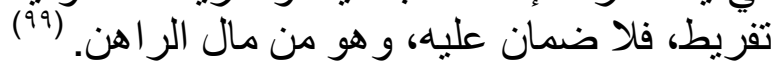

عمدة الشافعية و الحنابلة:

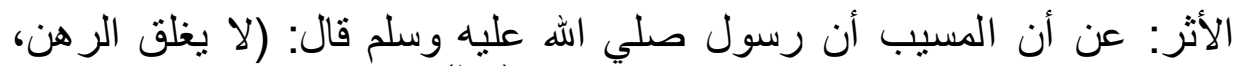

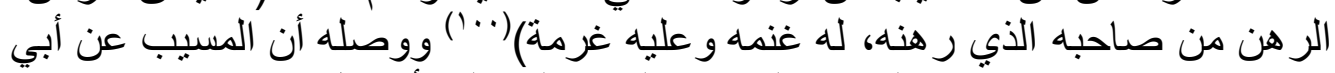
هريرة رضي الله عنه عن النبي صلي الله عليه وسلم مثله، أو مثل معناه من حديث ابن اله أبي أنبسة.

قال الثافعي:" وبهذا نأخذ وفيه دليل على أن جميع ما كان رهنا غير مضمون

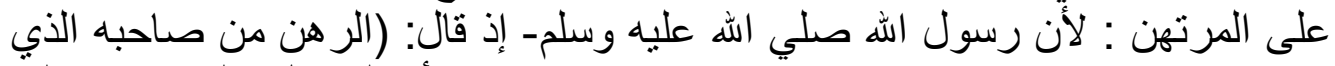

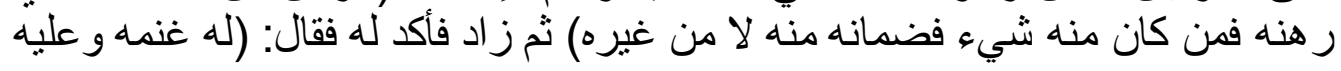


غرمه) و غنمه سلامته وزيادته و غرمه عطبه ونه ونقصه فلا يجوز فيه إلا أن يكون ضمانة من مالكه لا من مرتهنه. (1.")

القياس: وذلك أن الضمان إنما يكون بما تعدي الحابس بحبسه كالغصب أو بالمخاطرة

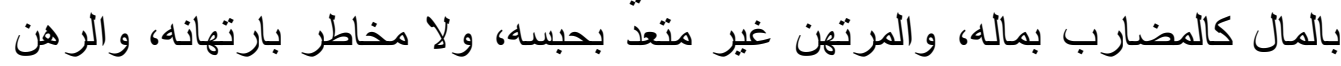

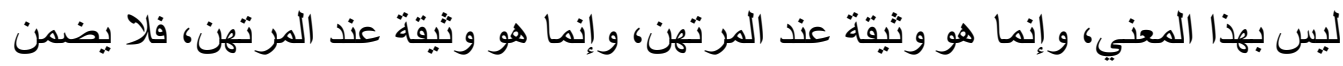
كالزيادة على قدر الدين وكالكفيل و الثناهد.

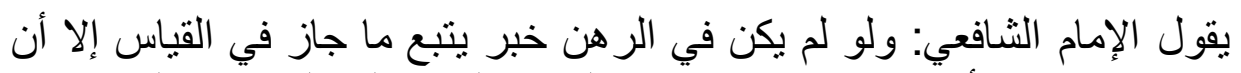

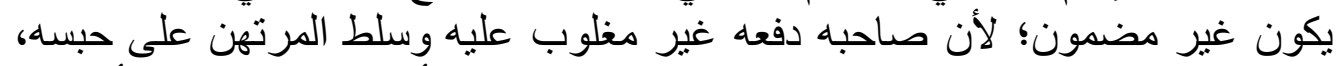

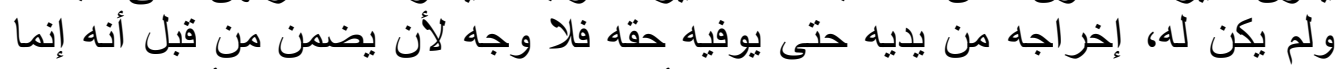

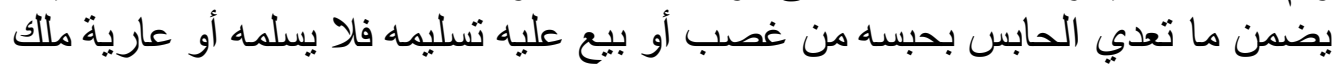

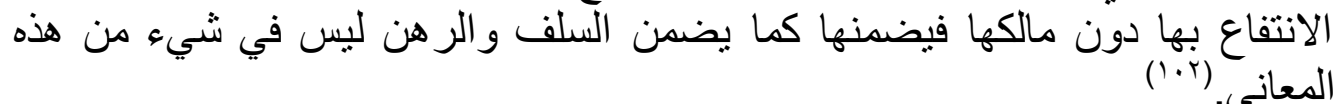

ويقول:" و إذا لم يخص رسول الله صلي الله عليه وسلم ر هنا دون ر هن فلا يجوز

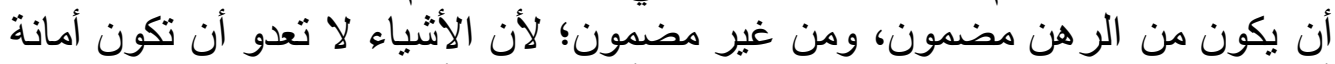

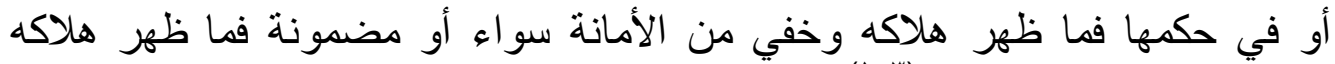

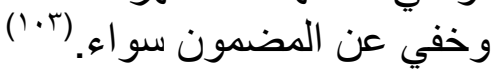

المسألة الثالثة: تضمين الصناع:

لا خلاف بين الأئمة في أن الأجير الخاص ليس بضامن لما هلك في يده مما

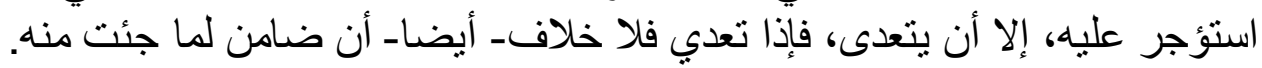

جاء في بداية المجتهد:" فأما بالتعدي: فيجب على المكري باتفاق.... و لا خلاف

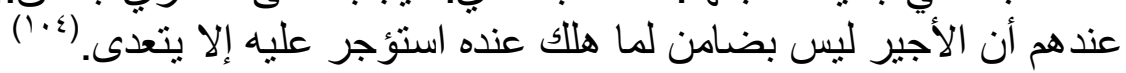

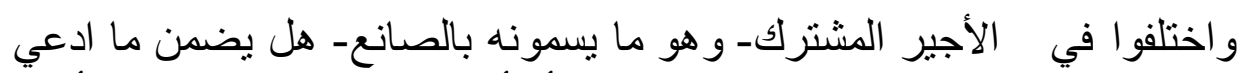

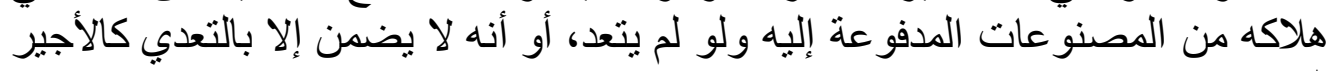
الخاص؟ هن هن

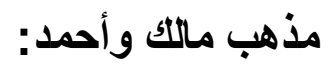

ذهب مالك و أحمد- رحمهما الله تعالى- إلى أنه ضامن مطلقا. 
قال في بداية المجته:" و أما تضمين الصناع ما ادعوا هلاكه من المصنو إلهات

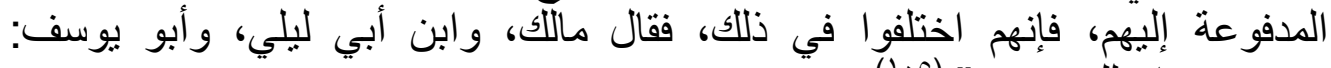

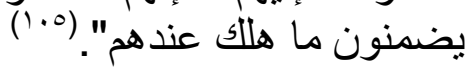

قال الخرقي:" وما حدث في السلعة من يد الصانع ضدن. (†.') قال ابن قدامة: الأجير المشترك هو الصانع الذي ذكره الخرقي، وهو ضامن إنامن لما

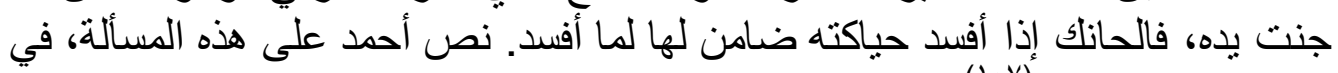

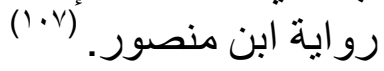

\section{عمدة مالك وأحمد:}

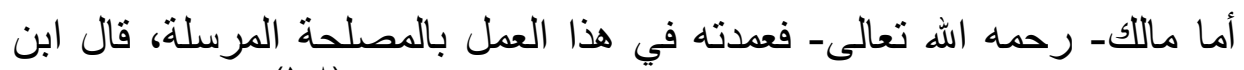

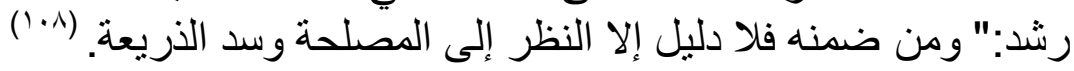

ووجه هذه المصلحة أنهم لو لم يضمنو الاستهانو ا بالمحافظة على أمتعة الناس

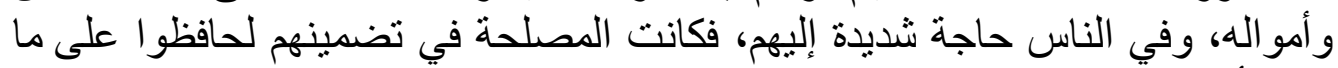
تحت أيديهم.

و أما أحمد بالرغم من أنه يري ما يراه ماللك، إلا أنه اختلف معه في الدليل فإنها

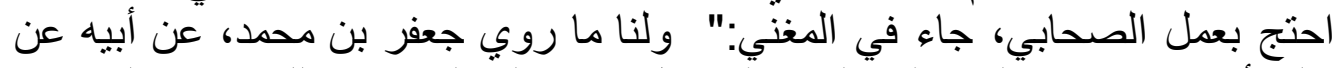

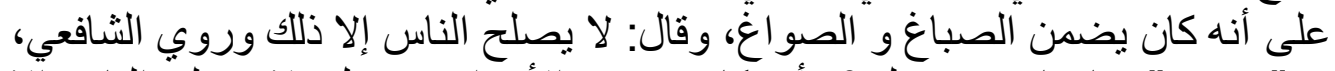

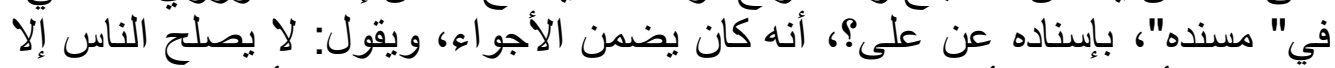

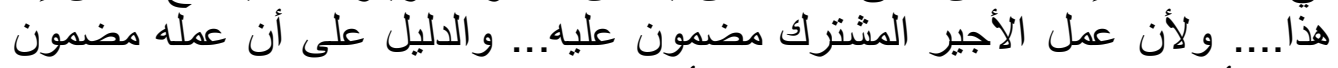

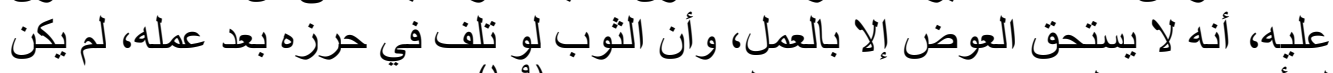

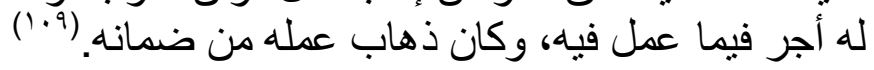
مذهب أبي حنيفة والشافعي:

ذهب أبو حنيفة والثافعي- رحمهما الله تعالى- إلى أنه لا يضمن إلا بالتعدي.

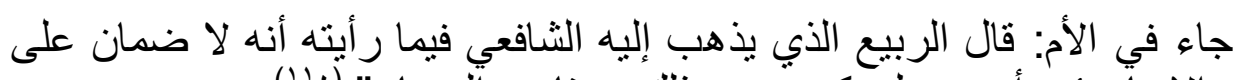

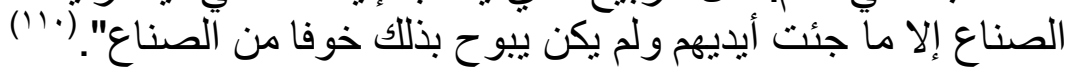




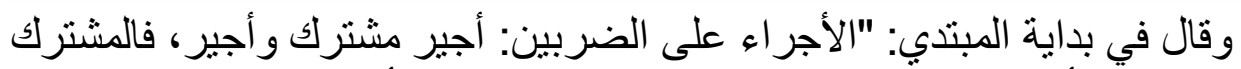

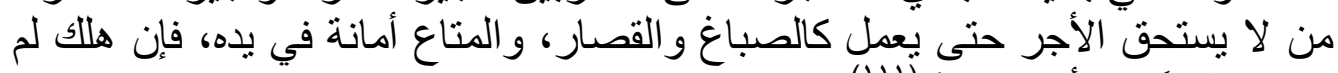
يضمن شيئً عند أبي حنيفة.

عمدة الحنفية و الشافعية:

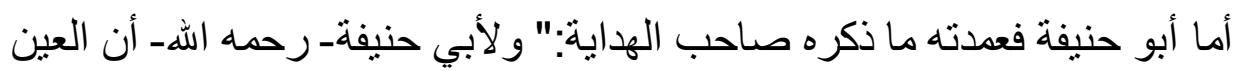

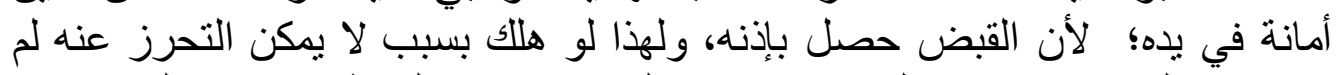

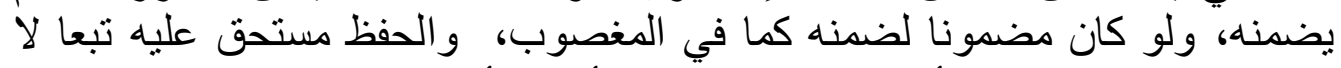

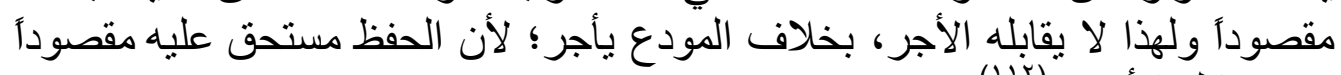

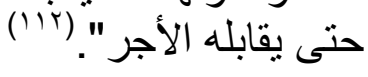
عنده". قال) ابن رشد:" وعمدة من لم ير الضمان عليهم أنه شبه الصانع بالمودع

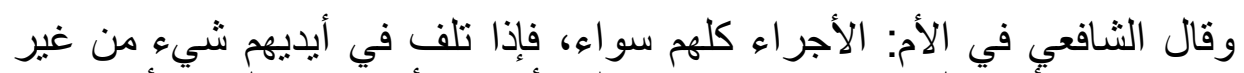

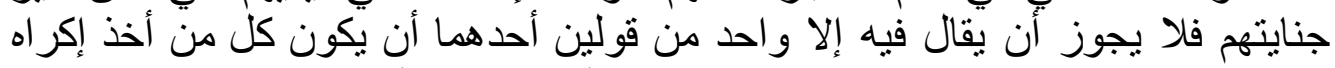

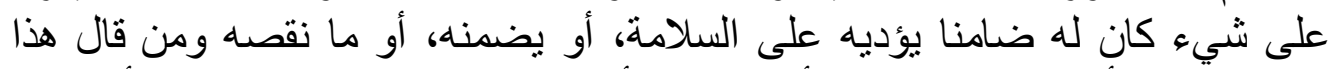

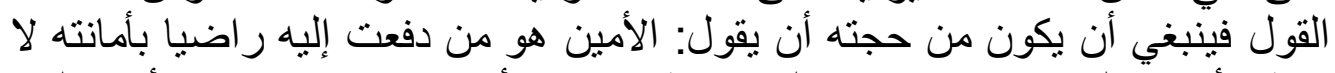

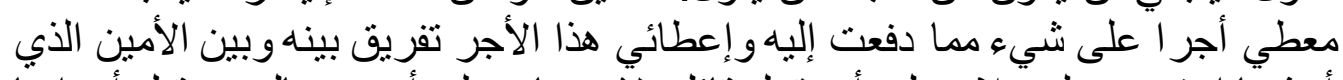

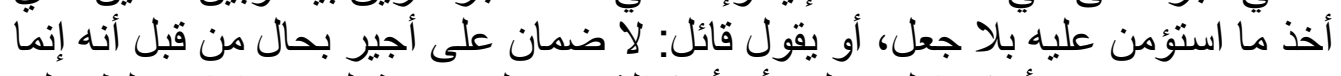

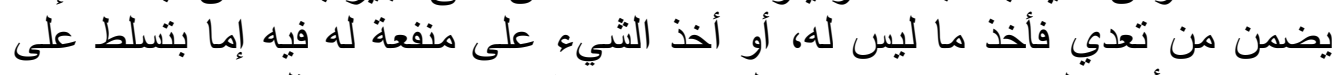

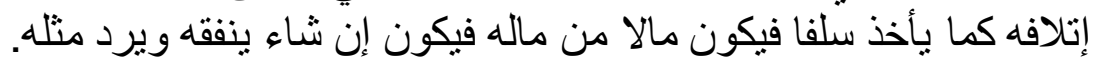

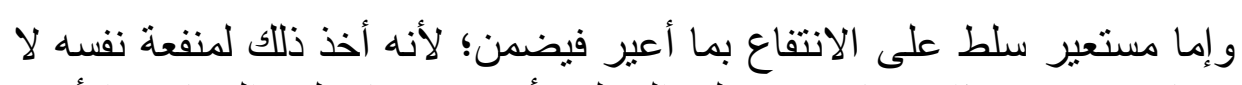

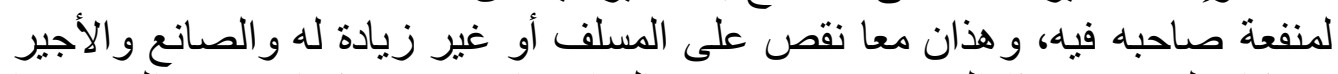

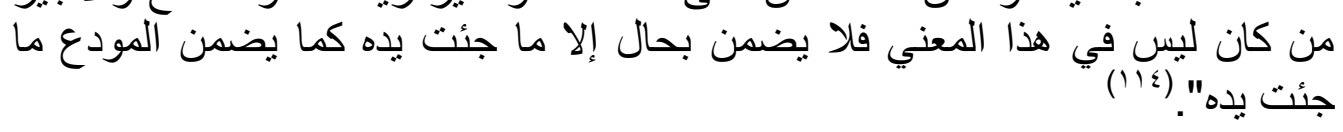

و إذا ثبت هذا أنه لا ضمان على الأجراء فلا فرق بين أجير وأجير إلا بدليل و لا الها

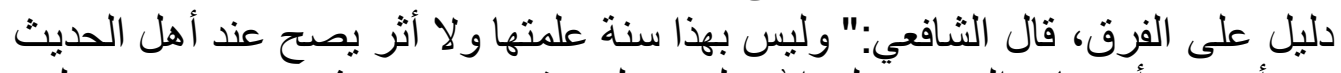

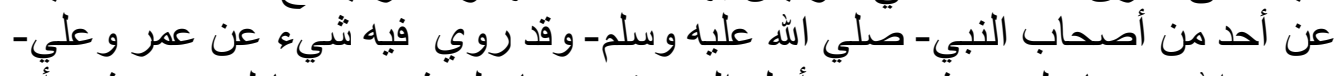

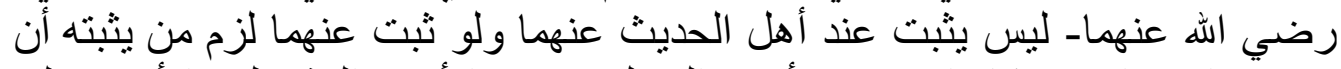

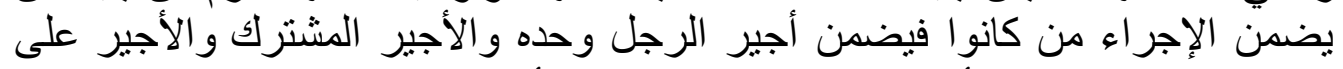

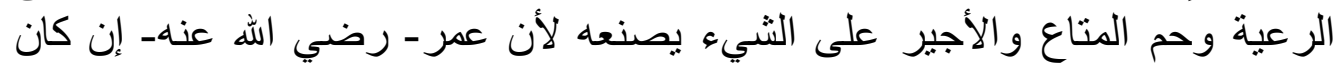




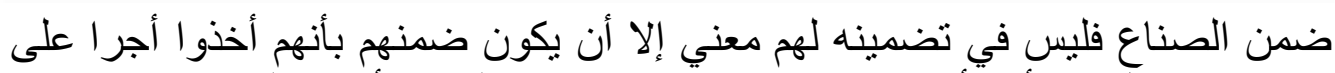

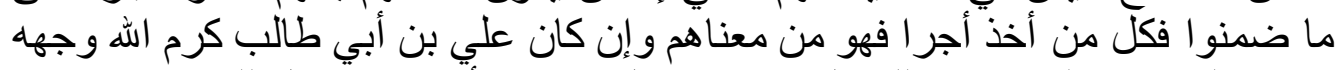

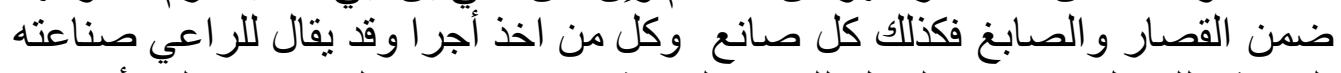

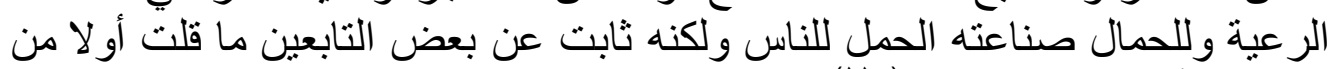
التضمين أو ترك التضمين". (110)

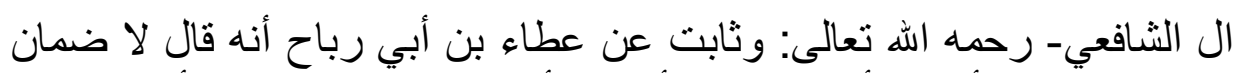

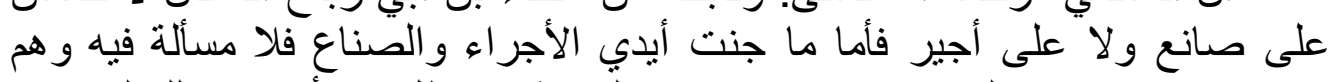

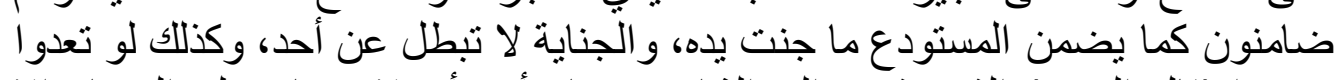

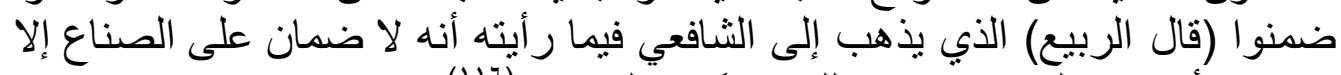

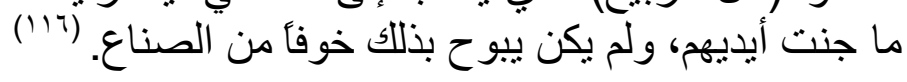

\section{خاتمة البحث}

تناولت في هذا البحث دليل الاستصلاح، ومن خلال دراسة هذا الموضوع خلصت إلى جملة من النتائج و هي:

1 - أن الثريعة الإسلامية تقوم على أساس مر اعاة مصالح العباد في المعاش و المعاد

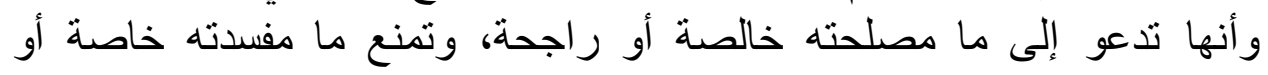
راجحة.

r- المصالح المرسلة هي التي لم يقم الدليل الخاص على اعتبار ها ولا على إلغائها

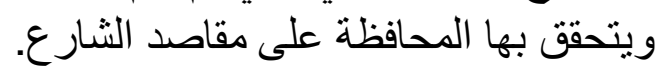

ץ- مجال العمل بالمصالح المرسلة هو جانب العبادات المتصلة بالتعامل بين بني الإنسان في سائر تصرفاتهم.

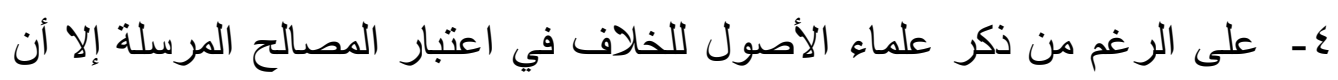

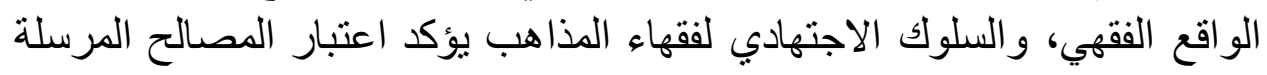

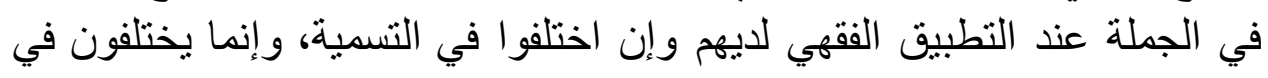

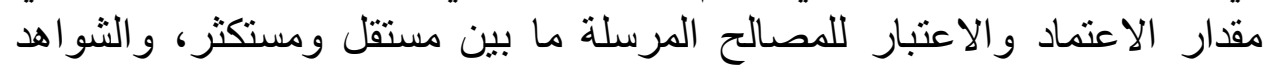

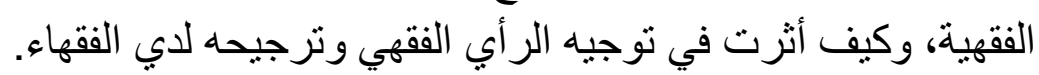


مجلة معالم الدعوة الإسلامية المحكمة. العدد (الثامن)- صفر VT ا ا هـ / ديسمبر 10 • rم

هـ - ظهر لنا تأثير اعتبار المصالح المرسلة في الفروع الفقهية، وكيف أثرت في توجيه الرأي الفقهي وترجيحه لدي الفقهاء.

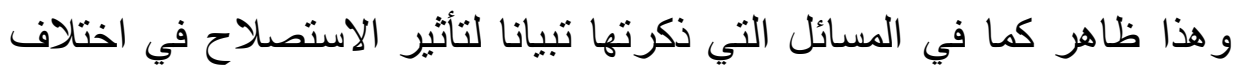

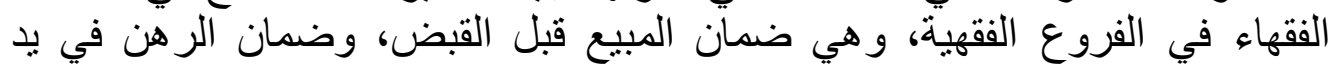
المرتهن، وتضمين الصناع.

والحمد لله أولاً وأخراً 
1 ـ أصول السرخسي: محمد بن أحمد بن سهل شمس الأئمة السرخسي، دار المؤيد-

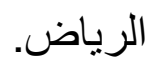

$$
\text { r - إعلام الموقعين: ابن قيم الجوزية، دار الجيل- بيروت. }
$$

r- الإحكام في أصول الأحكام: لأبي الحسن سيف الدين علي بن أبي علي بن محمد بن سالم الثعلبي الآمدي، دار الكتاب العربي- بيروت.

ـ - الاعتصام: إبراهيم موسي بن محمد اللخمي الغرناطي الثاطبي، دار الكتاب

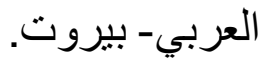

ــ الأعلام قاموس تراجم لأشهر الرجال والنساء من العرب والمستعربين و المستشرقين: خير الدين بن محمود بن محمد الزركلي الدمشقي، الناشر دار العلم

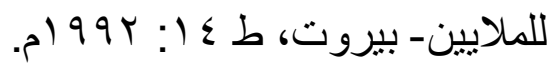

7- الأم: لأبي عبد الله محمد بن إدريس بن العباس عبد المطلب بن عبد مناف المطلبي

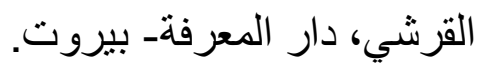

V- البحر المحيط في أصول الفقه: لأبي عبد الله بدر الدين محمد بن عبد الله بن بهادر

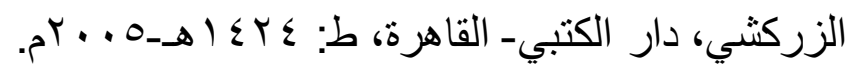

1ـ البرهان في أصول الفقه: عبد الملك بن عبد الله بن يوسف بن محمد الجويني الملقب بإمام الحرمين، دار الوفاء- المنصورة:

9- الرسالة: محمد بن إدريس الثافعي، تحقيق: أحمد شاكر، الناشر: مكتبة الحلبي،

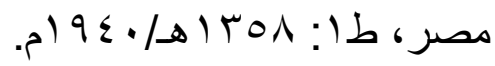
• ـ ـ الثافعي: محمد أبو زهرة، دار الفكر العربي- القاهرة.

إ- المبسوط: محمد بن أحمد بن سهل شمس الأئمة السرخسي، دار المعرفةـ

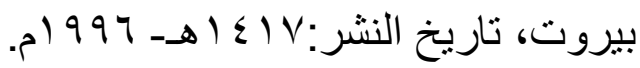




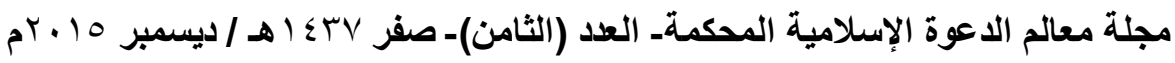

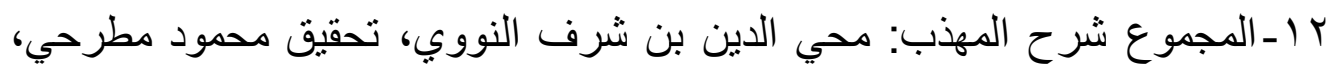

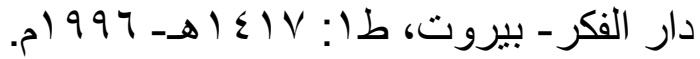

س ا ـ المجموع شرح المهذب: محي الدين يحي بن شرف النووي، دار الفكر - بيروت. ع اـ المحصول: لأبي عبد الله محمد بن عمر بن الحسن بن الحسين التيمي الرازي

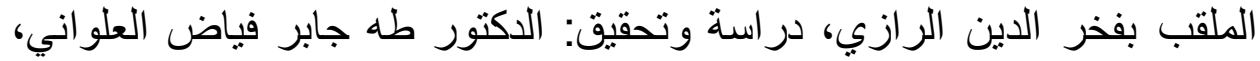

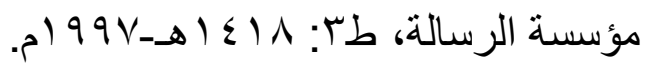

0 ـ ـ المستصفي: لأبي حامد محمد بن محمد الغز الي الطوسي تحقيق: محمد عبد السلام

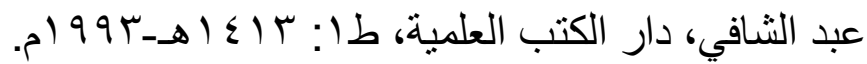

7 ا ـ المغني في فقه الإمام أحمد بن حنبل الثيباني: عبد الله بن أحمد بن قدامة المقدسي

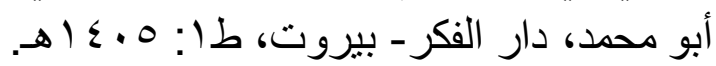

V ا المو افقات: إبراهيم بن موسي بن محمد اللخمي الغرناطي الثاطبي، دار إحياء

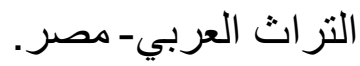

1 ا ـالهاية في شرح بداية المبتدي: علي بن أبي بكر بن عبد الجليل الفرغاني

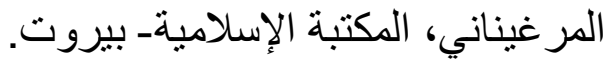

9 ا ـبداية المجتهر ونهاية المقتصد: محمد بن أحمد بن محمد بن رشيد القرطبي أبو

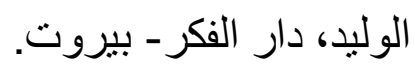

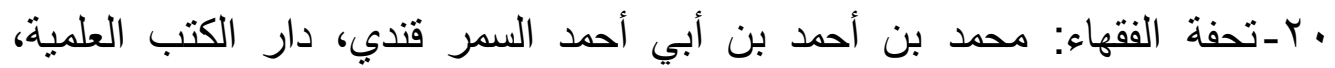

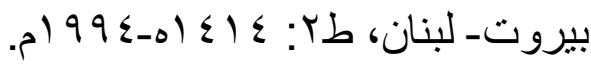

ابـ تخريج الفروع علي الأصول: محمود بن أحمد بن محمود شهاب الدين الزنجاني،

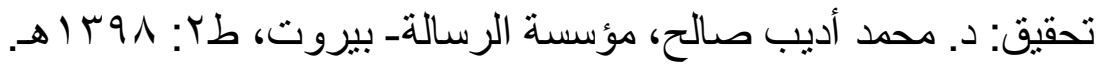

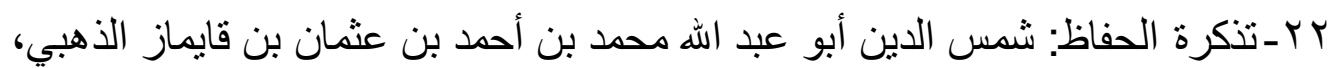
دار إحياء التراث العربي- بيروت لبنان. 


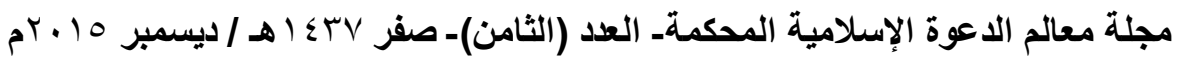

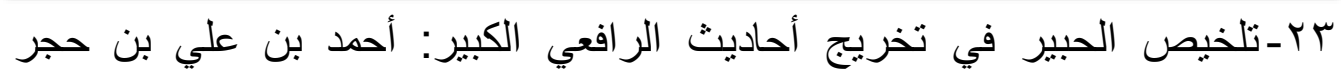

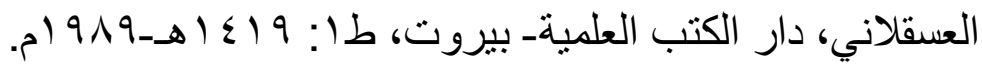

ع - -روضة الناظر وجنة المناظر في أصول الفقه على مذهب الإمام أحمد بن حنبل:

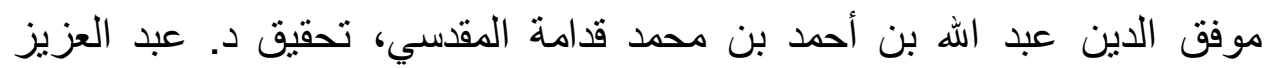

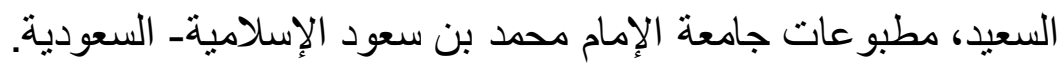

هץ-سير أعلام النبلاء: شمس الدين محمد بن أحمد بن عثمان بن قايماز الذهبي،

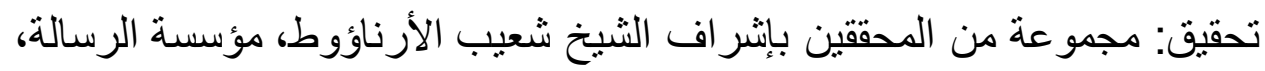

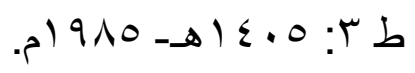

جr -شرح العضد على مختصر المنتهي للإيجي، دار الكتب العلمية- بيروت.

rV - شرح المحلي على جمع الجوامع: تاج الدين عبد الوهاب بن علي السبكي، مطبوع

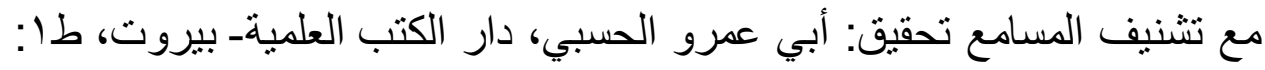

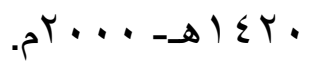

^ץ-شرح تنقيح الفصول: شهاب الدين أحمد بن إدريس بن عبد الرحمن المالكي القر افي، دار الفكر - بيروت. تلفوح الفهوت

و -شرح فتح القدير : محمد بن عبد الواحد السيو اسي، دار الفكر - بيروت.

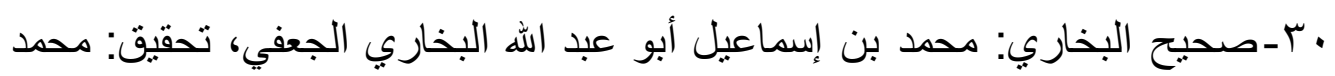

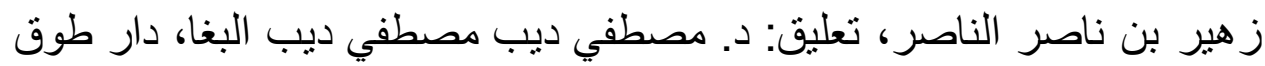

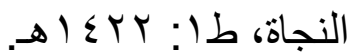

ابـصحيح مسلم: مسلم بن الحجاج أبو الحسن القتيري النيسابوري: تحقيق: محمد

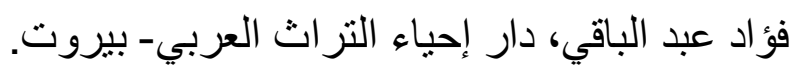

r - ضو ابط المصلحة المرسلة: البوطي، المكتبة الامويةـ دمشق. بس-طبقات الثافعية: للإمام أبي بكر بم أحمد بن محمد ابن قاضي شهبة الدمشقي،

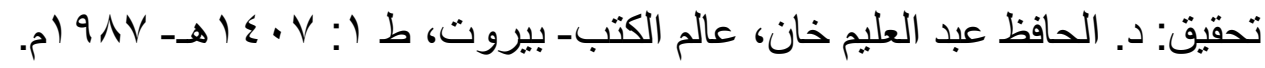


ع بـكثف الأسرار شرح أصول البزودي: عبد العزيز بن أحمد بن محمد، علاء الدين

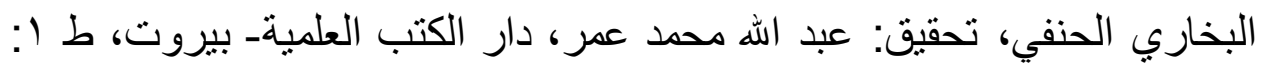

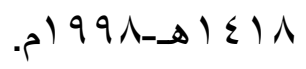

هr-كثف الأسر ار: للنسفي، دار الكتب العلمية.

جسـلسان العرب: محمد بن مكرم بن علي، أبو الفضل، جمال الدين ابن منظور

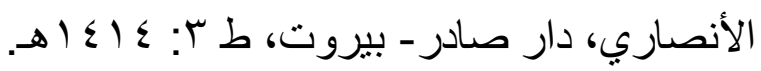

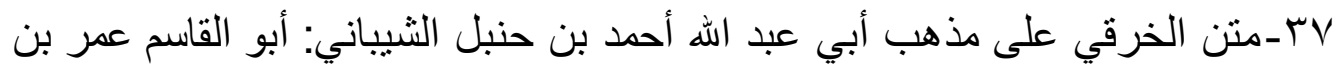

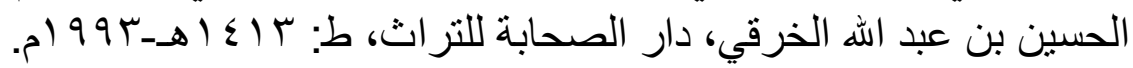

^ץ ـمنن بداية المبتدي في فقه الإمام أبي حنيفة: علي بن أبي بكر بن عبد الجليل

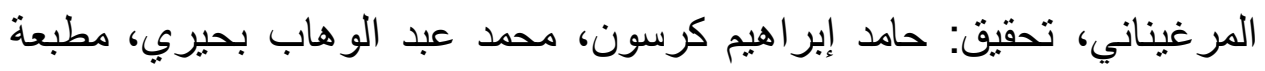

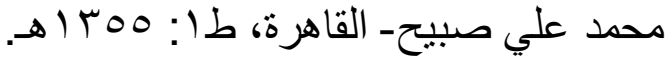

q" ـمصادر التشريع فيما لا نص فيه: عبد الوهاب خلاف، دار القلم- الكويت.

• ـ ـمغني المحتاج إلى معرفة معاني ألفاظ المنهاج: محمد الخطيب الثربيني، دار الفكر - بيروت.

اءــمنهاج الطالبين وعمدة المفتين: يحي بن شرف النووي أبو زكريا، دار المعرفةـبيروت.

Y ـ ـ نصب الر اية لأحاديث: جمال الدين أبو محمد عبد الله بن يوسف بن محمد الزيلعي،

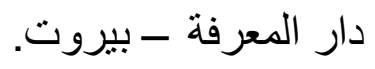

بـ ـ نظرية المصلحة في الفقه الإسلامي: د. حسين حامد حسان- دار المتنبي- القاهرة،

$$
\text { م) } 911
$$

ـ ــنهاية السول شرح منهاج الوصول: عبد الرحيم بن الحسن بن علي الأسنوي

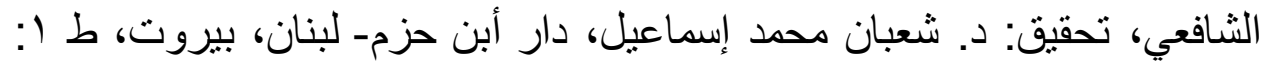

$$
\text { م) } 999-1 \leqslant r \text {. }
$$




\section{الهوامش:}

(1) قال الثاطبي: إن وضع الثرائع إنما هو لمصالح العباد في العاجل والآجل معا.

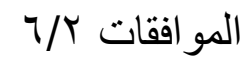

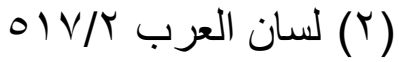

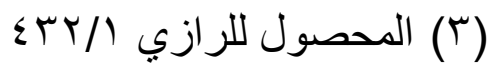

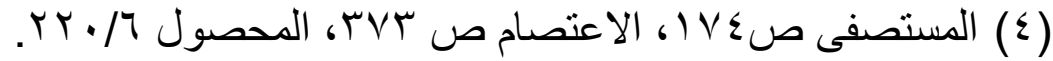

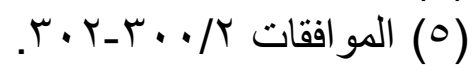

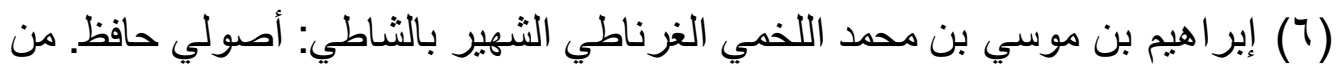

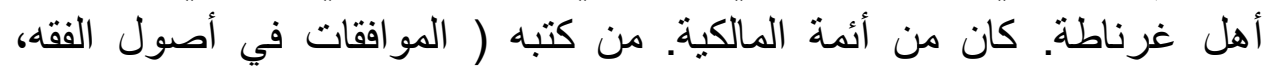

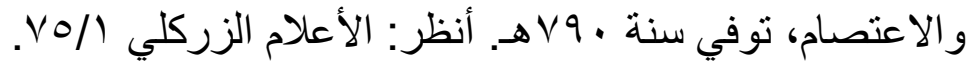

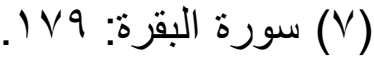

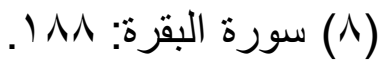

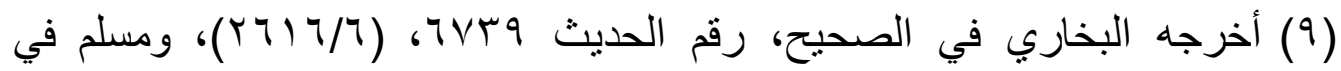

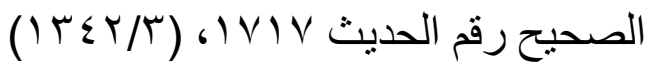

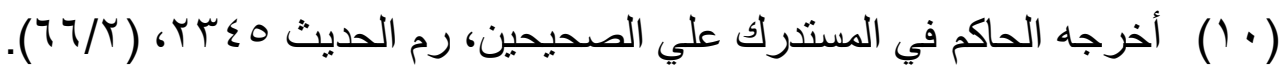

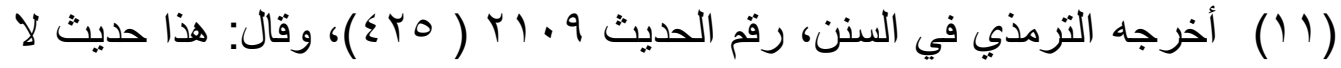

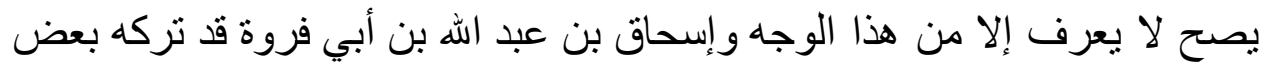

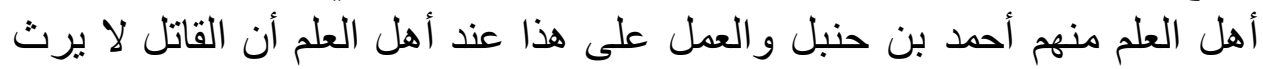

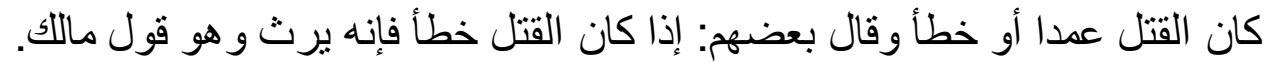

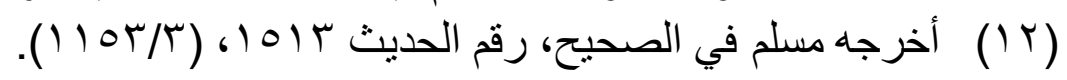

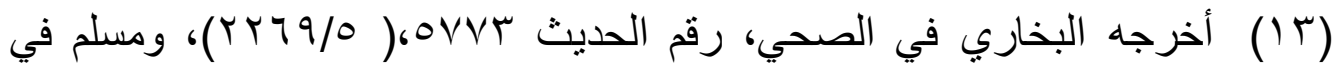

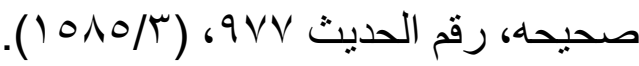

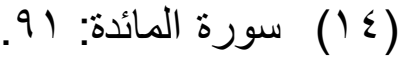

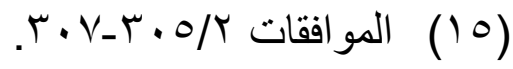

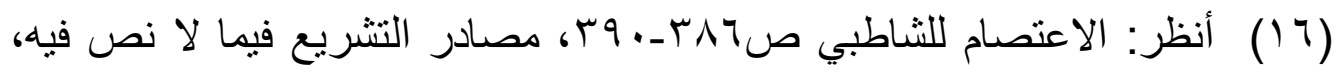

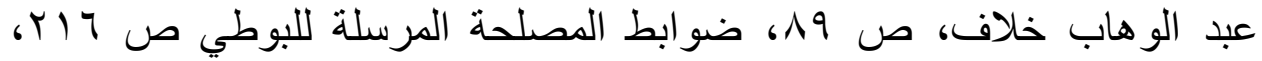
المكتبة الاموية- دمشق.

$$
\text { (IV) }
$$

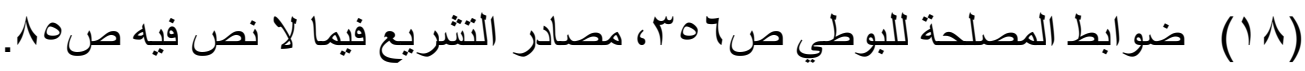


(9 (1) انظر: روضة الناظر وجنة الناظر في أصول الفقه على مذهب الإمام أحمد بن

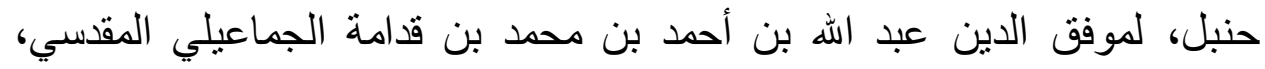

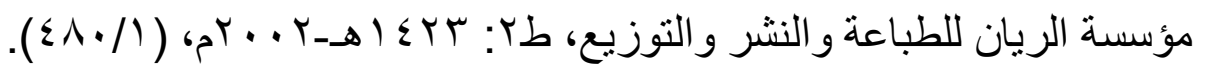

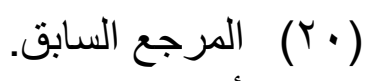
أحمد بن إدريس بن عبد الرحمن، أبو العباس، شهاب الدين الصنهاجي القرافي (Y) (Y)

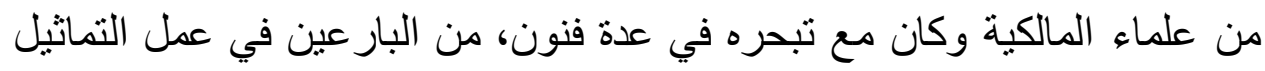

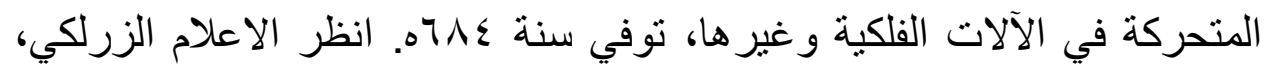

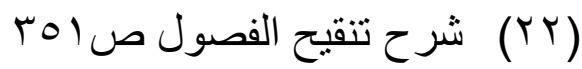

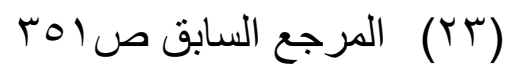

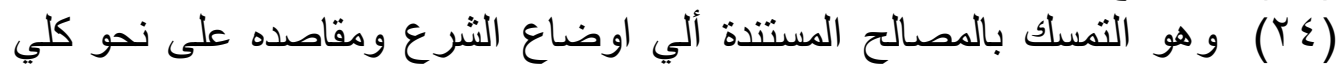

$$
\text { وان لم المو اقيتند إلي اصل جزئي }
$$

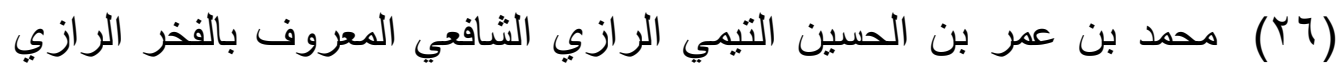

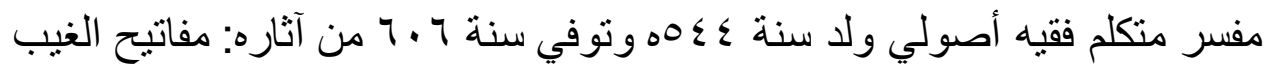

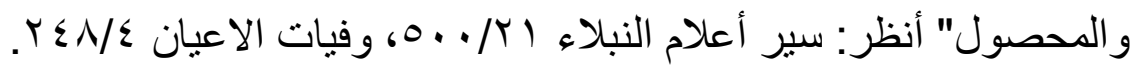

$$
\begin{aligned}
& \text { r سورة الحشر: (YV) } \\
& \text { (YN) } \\
& \text { (Yq) سورة المائدة: بوحه (Y) }
\end{aligned}
$$

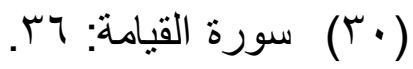

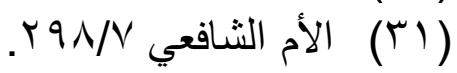

(Tr) ( علي بن أبي علي بن محمد بن سالم سيف الدين الآمدي شيخ المتكلمين في زمانه

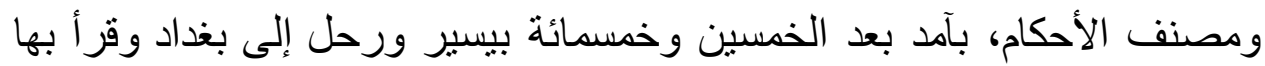

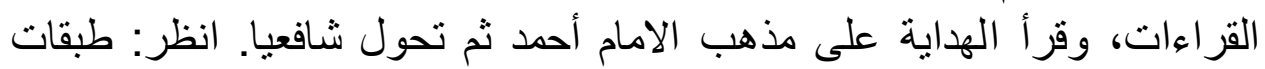

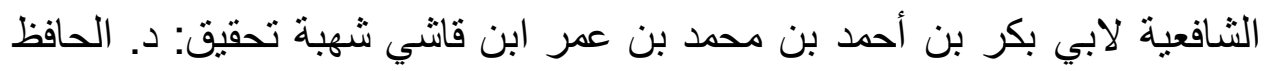

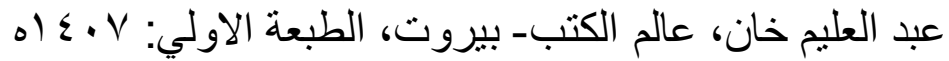

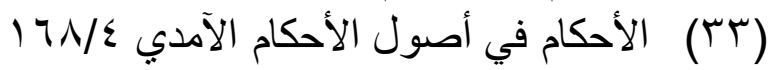

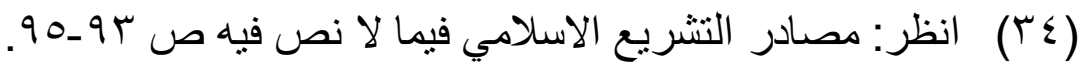

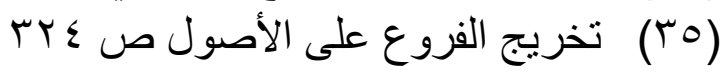




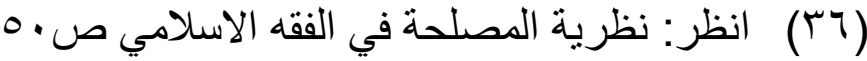

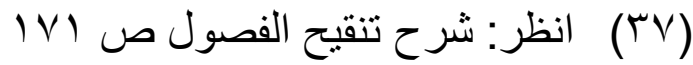

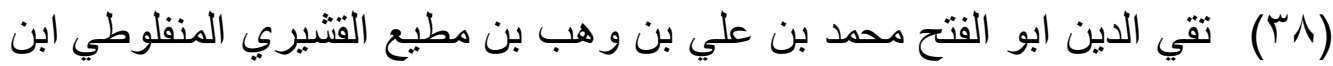

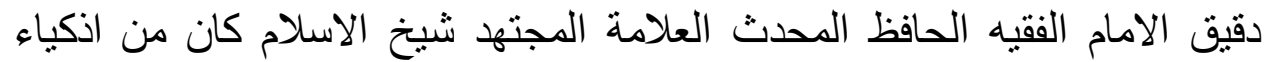

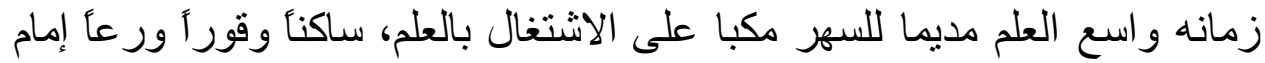

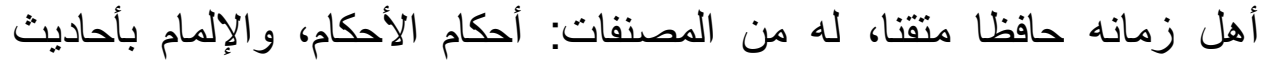

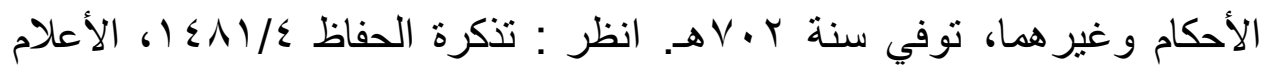

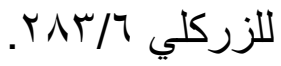

VV/T أنظر: (؟q)

( • (ع ) محد بن بهاذر بن عبد الله الزركثي أبو عبد الله بدر الدين، عالم بفقه الثافعية

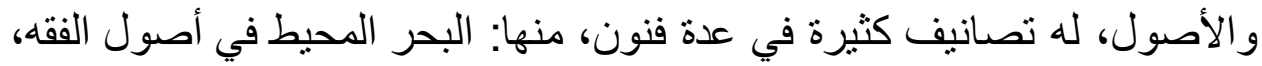

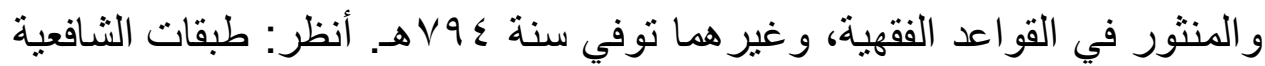

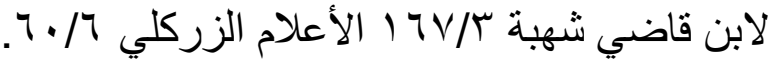

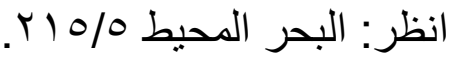

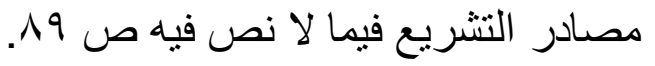

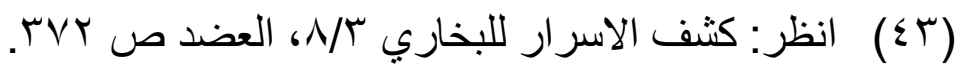

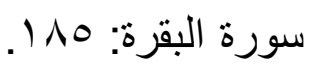

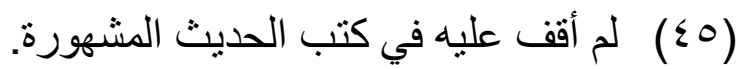

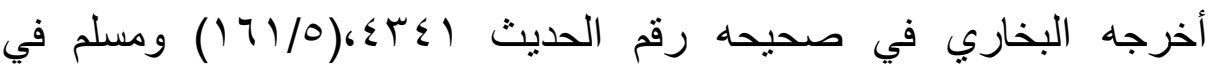

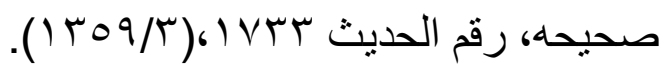

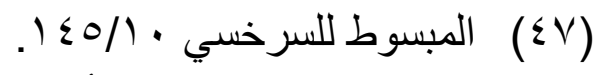

(\&ᄉ)

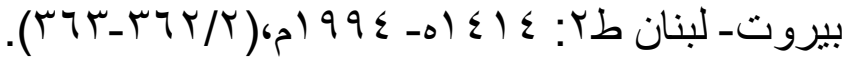

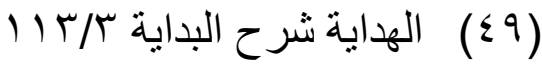

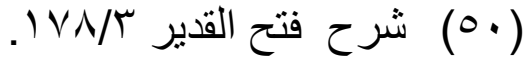

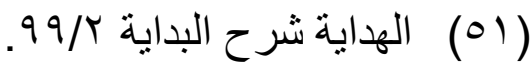

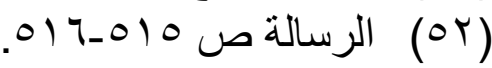

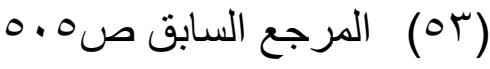

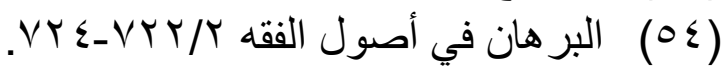




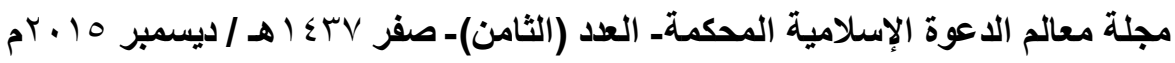

(07) محمود بن أحمد بن محمود بن بختيار، أبو المناقب شهاب الدين الزنجاني:

(00) (0) (0) المرجع السابق

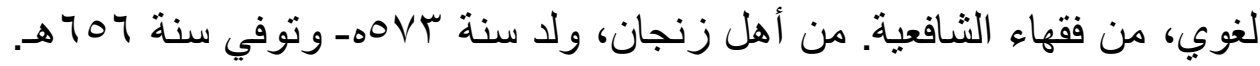

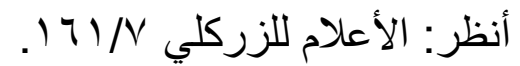

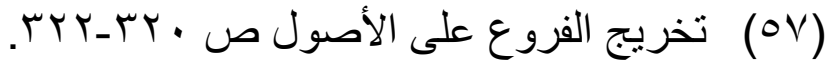

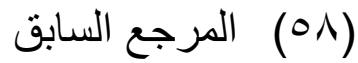

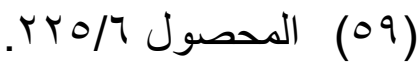

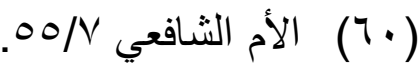

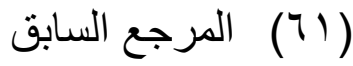

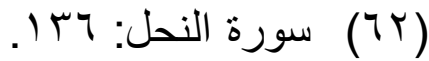

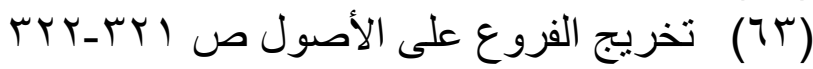

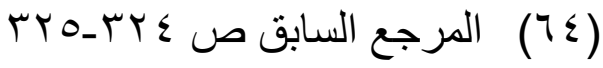

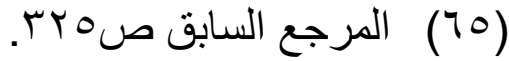

TVA-rVV/

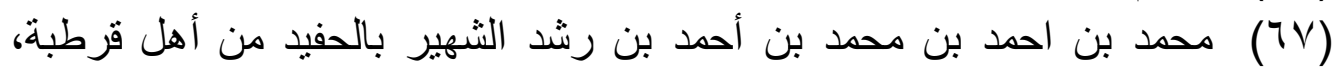

وقاضي الجماعة، درس الفقه و الاصول و علم الكلام، ولم ينشا بالأندلس مثله كمالا

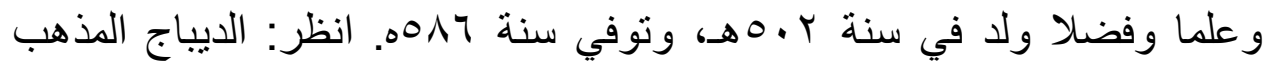

$$
\text { ص }
$$

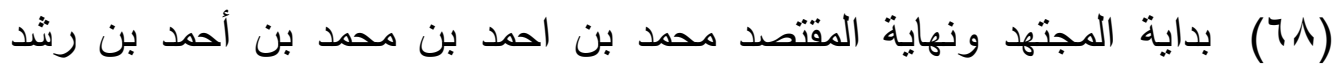

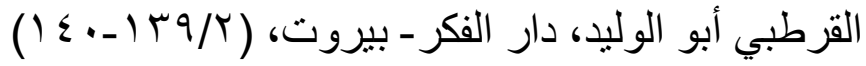

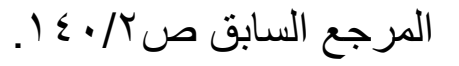

المغني في فقه الامام احمد بن حنبل الثيباني عبد الله بن احمد بن قدامة المقدسي (V•)

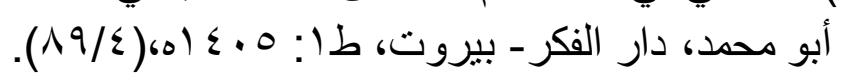

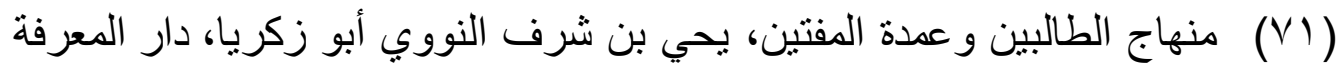

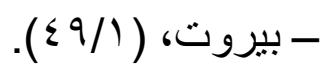

(VY)

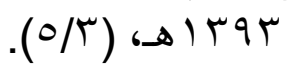

(VT) . ( 


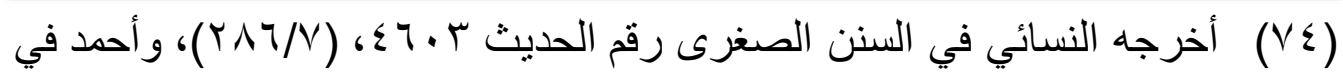

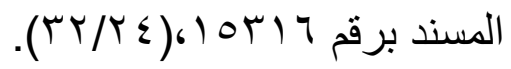

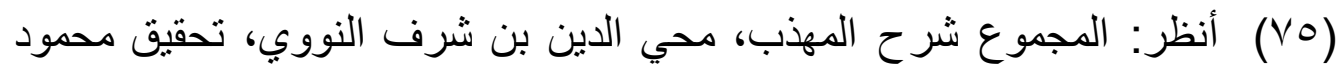

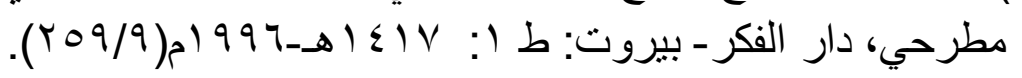

(VT)

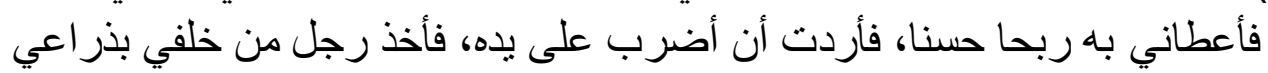

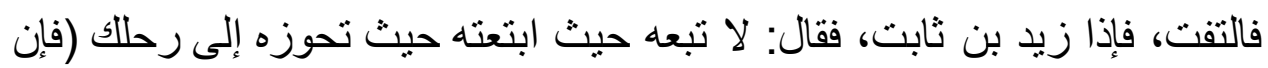

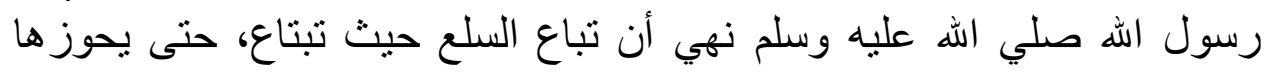

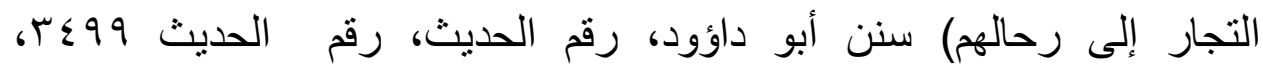

( $(r \wedge r / r)$

أخرجه البخاري في صحيحه، رقم الحديث Tr/Y (VV)

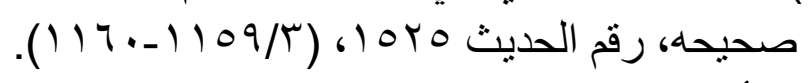

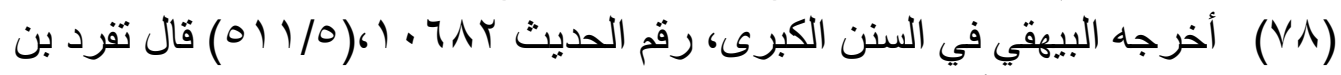
يحي ابن صالح الأيلي وهو منكر بهذا الإسناد.

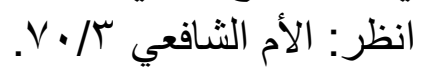

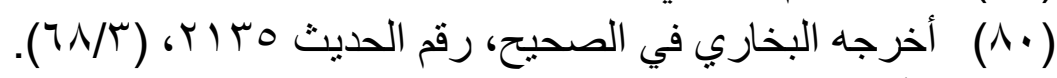

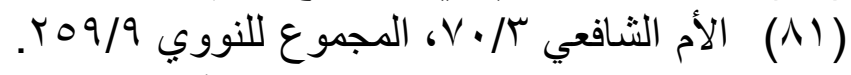

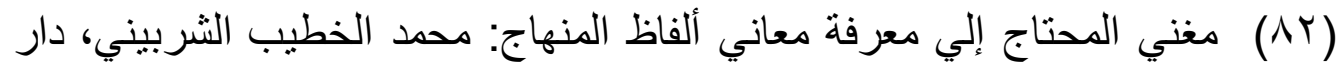

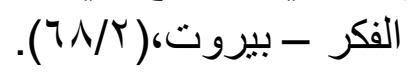

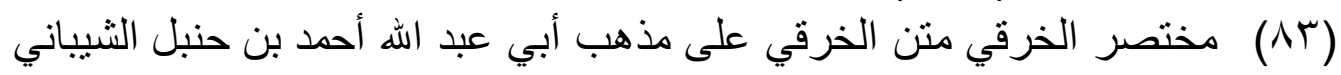

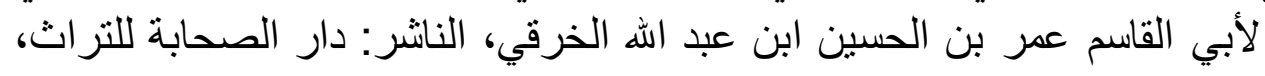

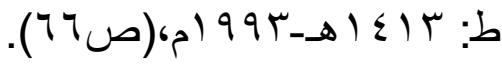

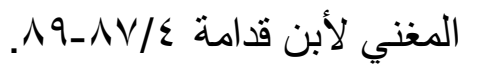

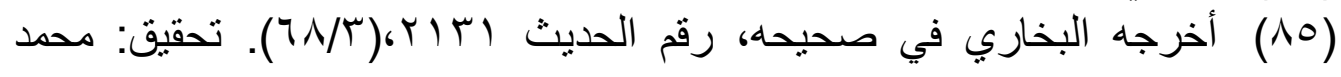

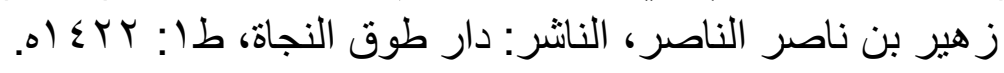
(AT)

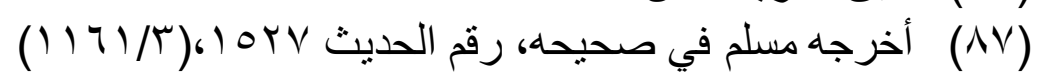

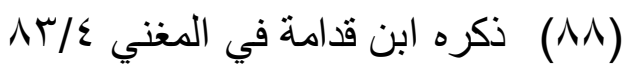


(19) أصله أن رجلا انتري غلاما في زمن رسول الله صلي الله عليه وسلم فكان

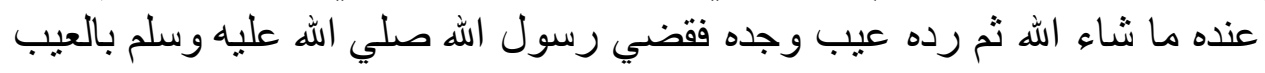

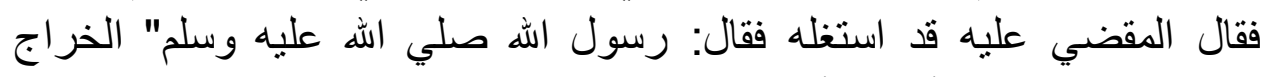

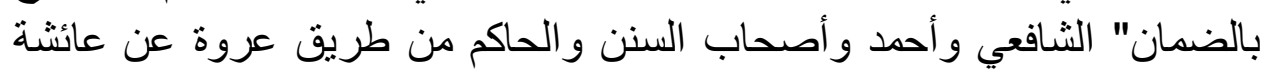

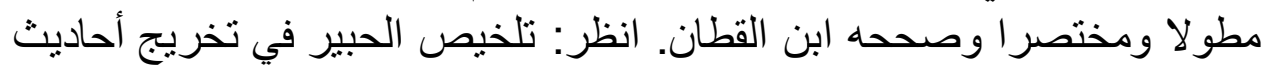

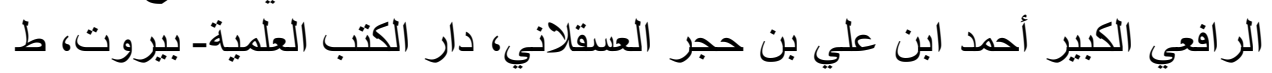

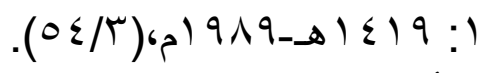

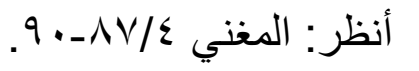

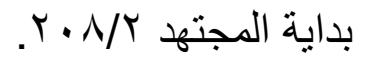

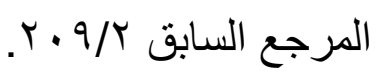

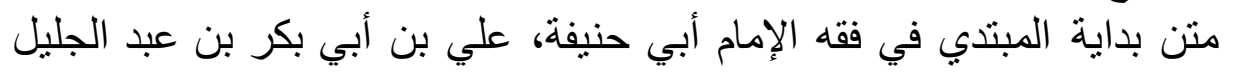

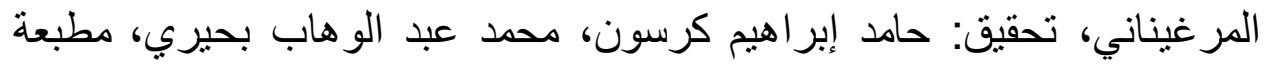

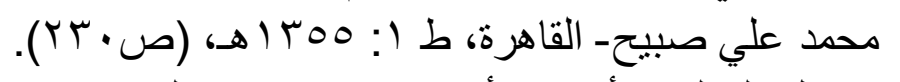

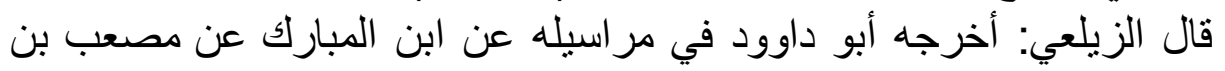

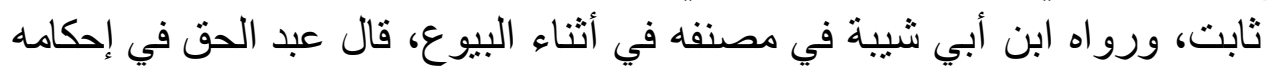

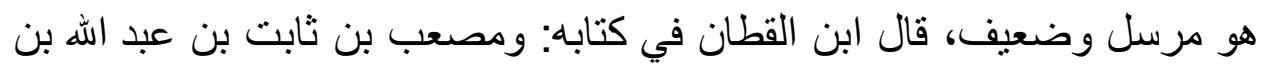

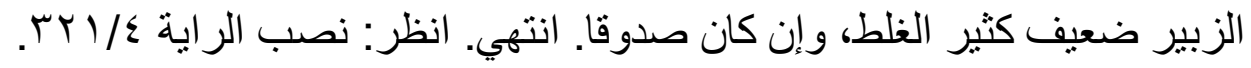

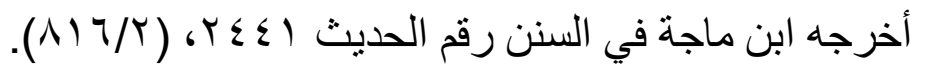

$$
\begin{aligned}
& \text { سورة القيامة: } 1 \text { بـ }
\end{aligned}
$$

(9V)

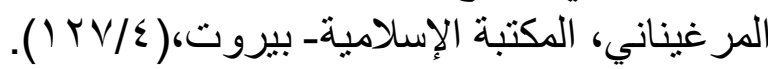

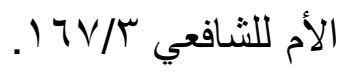

$$
\begin{aligned}
& \text { المغني \&OV/ }
\end{aligned}
$$

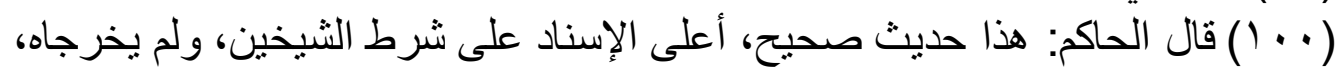

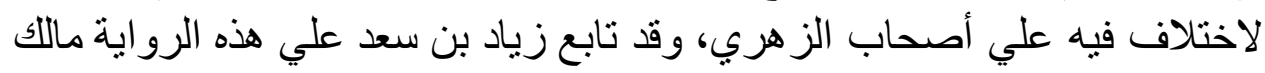

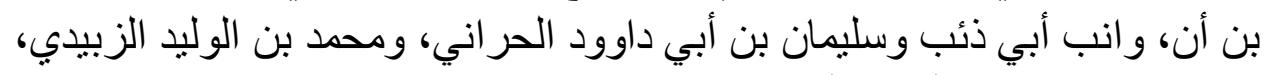

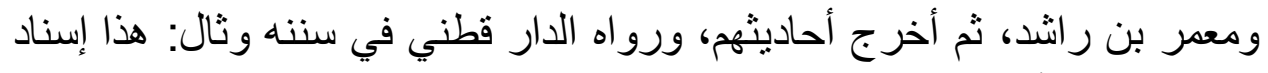

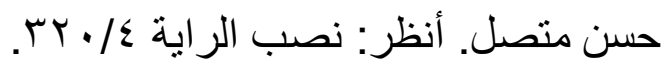

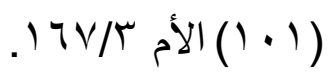




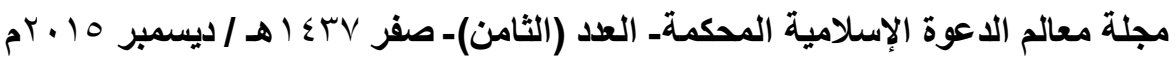

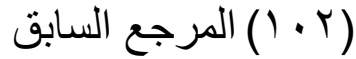

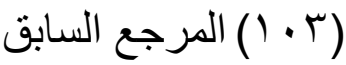

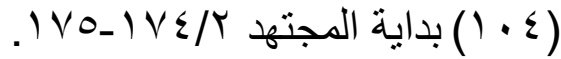

$$
\begin{aligned}
& \text { (1) (1) المرجع السابق }
\end{aligned}
$$

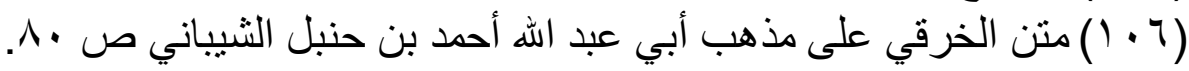

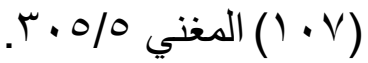

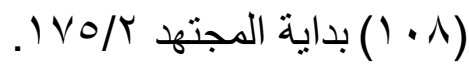

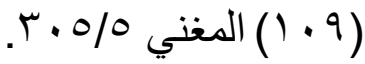

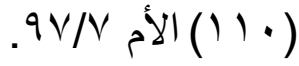

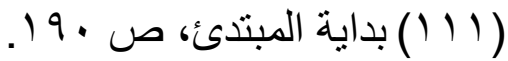

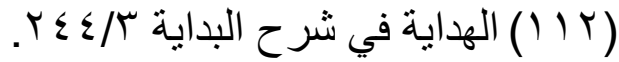

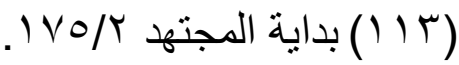

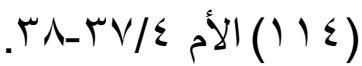

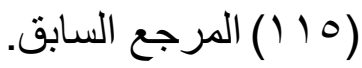
الأم 